Hydrol. Earth Syst. Sci. Discuss., https://doi.org/10.5194/hess-2018-360

Manuscript under review for journal Hydrol. Earth Syst. Sci.

Discussion started: 7 August 2018

(c) Author(s) 2018. CC BY 4.0 License.

1 Hydrogeological responses to the 2016 Gyeongju earthquakes,

\title{
2 Korea
}

3 Jaeyeon Kim ${ }^{1}$, Jungjin Lee ${ }^{1}$, Marco Petitta ${ }^{2}$, Heejung Kim ${ }^{1}$, Dugin Kaown ${ }^{1}$, In-Woo Park ${ }^{1}$,

4 Sanghoon Lee ${ }^{1}$ and Kang-Kun Lee ${ }^{1 *}$

$5{ }^{1}$ School of Earth and Environmental Sciences, Seoul National University, Seoul 08826, Republic of Korea.

$6 \quad{ }^{2}$ Department of Earth Sciences, Sapienza University of Rome, P.le A. Moro 5, 00185 Rome, Italy.

$7 \quad$ Correspondence to: Kang-Kun Lee ${ }^{1 *}$ (kklee@snu.ac.kr) 


\section{Abstract}

The September 12, 2016 Gyeongju earthquakes (M5.1 and M5.8) had significant effects on groundwater systems along the Yangsan Fault System composed of NNE-trending, rightlateral strike-slip faults in Korea. Hydrological changes induced by the earthquakes are important because no surface ruptures have been reported and few earthquakes usually occur in Korea. The main objective of this research was to propose a conceptual model interpreting the possible mechanisms of groundwater response to the earthquakes based on anomalous hydrogeochemical data including isotope (radon, strontium) concentrations with bedrock characteristics. To analyze the hydraulic changes resulting from the earthquakes, annual monitoring data of groundwater level, temperature, and electrical conductivity and collected data of hydrochemical parameters, radon-222, and strontium isotopes were collected during January 2017. Groundwater level anomalies could be attributed to the movement of the epicentral strike-slip fault. Radon concentration data showed the potential of groundwater mixing processes. Strontium anomalies could be related to the lithology and stratigraphy of the bedrock, reflecting the effect of water-rock interaction. Using a Self-Organizing Map (SOM) statistical analysis, associations of hydro-geochemical characteristics among groundwater wells were interpreted. By combining the grouped results of the SOM with lithostratigraphic unit data, 21 groundwater wells were classified into four groups, each corresponding to different hydrogeological behaviors. A new comprehensive conceptual model was developed to explain possible mechanisms for the hydrological and geochemical 
Hydrol. Earth Syst. Sci. Discuss., https://doi.org/10.5194/hess-2018-360

Manuscript under review for journal Hydrol. Earth Syst. Sci.

Discussion started: 7 August 2018

(c) Author(s) 2018. CC BY 4.0 License.

responses in each group, which have been respectively identified as water-rock interaction,

29 mixing of shallow and deep aquifers via sea water intrusion, bedrock fracture opening related

30

to strike-slip fault movement, and no response.

31

32

33 


\section{Introduction}

Earthquakes have a great influence on underground hydrology, such as water table changes and groundwater chemistry anomalies. Typically, most studies have focused on earthquake forecasting, i.e. changes prior to earthquakes. There have been few studies that discuss the responses of groundwater systems following earthquakes (Adinolfi Falcone et al., 2012;Amoruso et al., 2011;Barberio et al., 2017;Claesson et al., 2007;Ekemen Keskin, 2010;Galassi et al., 2014;Lee et al., 2013;Matsumoto et al., 2003;Petitta et al., 2018;Wang and Manga, 2010;Wang et al., 2012; Yechieli and Bein, 2002). Seismicity can cause abrupt changes or have long-term effects on the environment, particularly, groundwater systems. Seismic waves, for example, are known to cause changes in water level, temperature, and geochemistry (Matsumoto et al., 2003;Roeloffs et al., 2003;Roeloffs, 1998;Shi et al., 2015;Adinolfi Falcone et al., 2012; Wang et al., 2012). Hydrological responses to seismicity depend on several factors such as the earthquake magnitude, distance from the epicenter, the chemical and physical properties of the water, geological structures, permeability, and the pore pressure of rocks (Ekemen Keskin, 2010;Hartmann and Levy, 2005;Petitta et al., 2018). For example, Ekemen Keskin (2010) stated that the observed changes in aquifers could be explained using a dilatancy-fluid model; the response to earthquakes could be attributed to the changes in the water mixing ratio because of aquifer permeability, pore pressure, and flow path. Moreover, locally heterogeneous responses of groundwater have been observed and associated with the dominant lithology and mineralogy of bedrocks (Frape et al., 1984;Shand 
et al., 2009;Kim et al., 1996), local degree of deformation (Fitz-Diaz et al., 2011), or fracture networks allowing groundwater flow (Gray et al., 1991). By using hydraulic properties, some studies also have proposed some conceptual models for describing the aquifer responses to earthquakes (Adinolfi Falcone et al., 2012;Amoruso and Crescentini, 2010;Amoruso et al., 2011;Barberio et al., 2017;Manga, 2001;Roeloffs, 1998;Tokunaga, 1999).

On September 12, 2016, two earthquakes $\left(M_{L}=5.1\right.$ and $M_{L}=5.8$, respectively) occurred in Gyeongju, in the southeastern part of the Korean Peninsula (Korea Meteorological Administration). The $\mathrm{M}_{\mathrm{L}}$ of the mainshock was recorded as the largest in Korea since seismic monitoring started in Korea in 1978. The source mechanism of the Gyeongju earthquakes displayed strike-slip movement of a branch of the Yangsan Fault (YSF) passing through the Gyeongju area (Kim et al., 2017b;Kim et al., 2016). The occurrence of the Gyeongju earthquakes was shocking to people, as Korea has predominantly been recognized as seismically stable. Actually, the earthquake catalog over the past 2,000 years shows that

67 historically damaging earthquakes in Korea have mainly occurred in the southeastern part of the peninsula, particularly in the Gyeongju area near the YSF (Lee and Jin, 1991;Lee and Na, 1983). Slip analysis and earthquake focal mechanism solutions have interpreted that the YSF

70 is under a regional compressional stress field which might be a result of the continental 71 collision of the Pacific, Eurasian, and Indian plates (Jiang et al., 2016;Park et al., 2007;Park

72 et al., 2006;Zoback, 1992). The occurrence of the Gyeongju earthquakes provides an 73 opportunity for a more detailed study of the YSF and post-earthquake changes including 
74 groundwater responses, because some local hydrologic effects related to the lithology were

75 observed following the Gyeongju earthquakes.

76 The earthquake-related indicators in hydrogeology generally include (i) groundwater level,

77 (ii) temperature, (iii) hydrochemistry, and (iv) isotope concentrations. Groundwater level

78 monitoring has been broadly used to identify pre-, co-, and post- earthquake changes (Ben-

79 Zion and Aki, 1990;Brodsky, 2003;Manga et al., 2012;Roeloffs, 1998;Shi et al., 2015;Wang

80

81 and Manga, 2010). Seismic waves have been known to affect the groundwater level via oscillations and permanent offsets. Temperature changes are commonly analyzed using groundwater level data (Ekemen Keskin, 2010;Kitagawa and Koizumi, 2000). In this study, groundwater chemistry, major elements, and some physical-chemical parameters ( $\mathrm{pH}, \mathrm{EC}$, and temperature) were monitored. Among the isotopes, oxygen, hydrogen, and radon-222 were analyzed to determine the effects of the earthquake on groundwater. Radon-222, particularly, has been generally monitored as an earthquake precursor sampled in water or air (Igarashi et al., 1995;King, 1978;Liu et al., 1984;Noguchi and Wakita, 1977;Roeloffs, 1999; Teng, 1980;Wakita et al., 1980). Radon-222 is a radioactive nuclide with a half-life of approximately 3.8 days. It is produced from radium-226 in the natural radioactive decay chain of uranium-228; thus, its concentration is proportional to the uranium concentration in adjacent rocks. The transport of radon is influenced by fluid advection, diffusion, partition between the liquid and gas phases, and radioactive decay. The radon concentration in groundwater is dependent on the surface area of the rocks (Hoehn and Von Gunten, 
1989; Torgersen et al., 1990). Because the surface area can be affected by earthquakes, the radon concentration can increase or decrease. Radon-222 also shows significant anomalies at fault zones prior to earthquakes (Ghosh et al., 2009; Walia et al., 2009; Wang and Fialko, 2015). However, few studies have delineated the response of radon concentration to earthquakes. Strontium isotopes have been used in only a few earthquake-related papers. These isotopes are useful tracers for groundwater origin and water-rock mixing processes because ${ }^{87} \mathrm{Sr}$ is the daughter product of the natural decay of radioactive ${ }^{87} \mathrm{Rb}$ (half-life $=48.9$ $\mathrm{Ga}$ ). The ${ }^{87} \mathrm{Sr} /{ }^{86} \mathrm{Sr}$ ratio differs according to the rock type in the bedrock of aquifers (Frape et al., 1984;Frost and Toner, 2004;Négrel et al., 2004;Shand et al., 2009). Thus, strontium isotopes in groundwater can also reveal significant post-earthquake anomalies at fault zones according to bedrock type.

The main objective of this study was to identify hydrogeochemical changes related to the Gyeongju earthquake and then suggest a conceptual model of the response of the groundwater systems to the earthquake using the grouping results. In accordance with this objective, major research results were achieved via (i) performing a correlation and cluster analysis of hydrochemical parameters with geological characteristics using the SOM approach; (ii) analyzing pre-, co-, and post-seismic changes in groundwater level, temperature, and EC; and (iii) interpreting the results of isotopes (radon and strontium) sampled following the earthquake based on the grouping. These results could help to provide the possible mechanisms of groundwater changes induced by the earthquake. The overview 
Hydrol. Earth Syst. Sci. Discuss., https://doi.org/10.5194/hess-2018-360

of this research is shown in Fig. 1.

\section{Study area}

The Gyeongju earthquake sequence started with a foreshock $\left(\mathrm{M}_{\mathrm{L}}=5.1\right)$ at 10:44:32 UTC, on September 12, 2016, and the mainshock $\left(\mathrm{M}_{\mathrm{L}}=5.8\right)$ occurred at 11:32:55 UTC (Korea Meteorological Administration). During the first 10 days following the mainshock, more than 120 earthquakes of $M_{L} \geq 2.0$ were recorded in the epicentral region. The earthquakes, including the mainshock and strong aftershocks $\left(\mathrm{M}_{\mathrm{L}} \geq 3.5\right)$ are listed in Table 1 . Gyeonggi, and Youngnam from north to the south. The Gyeongsang Basin is the northern part of the Youngnam massif and the Yangsan Fault System has developed in the eastern part of the Gyeongsang Basin. The Yangsan Fault System is a group of NNE-trending major strike-slip faults. The Gyeongju earthquake and its abundant aftershocks occurred near the YSF (Fig. 2a), which has a linear expression for approximately $200 \mathrm{~km}$, and is the longest major fault of the Yangsan Fault System (Kyung and Lee, 2006). The displacement of the fault is approximately $21-35 \mathrm{~km}$ depending on the location, and the arrangement of the granitic rocks in this area indicates Cenozoic dextral strike-slip of $21.3 \mathrm{~km}$ in the $\mathrm{N} 20^{\circ} \mathrm{E}$ direction along the YSF line (Hwang et al., 2004;Hwang et al., 2007). 

proved its seismic activation (Kyung and Lee, 1999;Kyung and Lee, 2006;Lee and Jin, 1991). The Gyeongju area has been subject to most of the large historical earthquakes that have occurred in Korea. Initial movement on the YSF was recorded to have occurred before 45 Ma, based on radiometric dating of volcanic rocks (Chang et al., 1990). Age dating using the accelerator mass spectrometry (AMS) method indicates late Quaternary movement of the YSF between 2,400 and 2,000 yrs BP and an average vertical slip rate of approximately 0.04$0.05 \mathrm{~mm} / \mathrm{yr}$ (Kyung and Chang, 2001). Recent measurement of the vertical slip rate of YSF reported less than $0.1 \mathrm{~mm} / \mathrm{yr}$ on average $(0.02-0.07 \mathrm{~mm} / \mathrm{yr}$ in the southern part and $0.03-0.05$ $\mathrm{mm} / \mathrm{yr}$ in the northern part) (Kyung, 2003;Kyung and Lee, 2006), indicating that the YSF has been seismically active.

Paleo-stress analyses have noted that the stress regime of the YSF has changed more than three times (Kang and Ryoo, 2009;Kim et al., 1996), and during the Quaternary the ENEWSW maximum compression is in agreement with the first-order stress field in east Asia (Chang et al., 2010;Heidbach et al., 2010;Zoback, 1992). Trench analysis of the Yugye Fault, the youngest Quaternary fault in the northern part of the YSF, also yielded a NW-SE or WNW-ENE compressional local maximum principal stress (Kim and Jin, 2006). For the Gyeongju event, also under this ENE-WNW compression, geophysical studies of the 
(Hong et al., 2017;Kim et al., 2017a;Lee et al., 2018;Son et al., 2017).

Basin (Fig. 2b). The information for each well is shown in Table 2. The lithostratigraphic unit indicates the characteristic of the bedrock aquifer wells (labeled as KW\#\#-2). The Gyeongsang Basin is mainly composed of Cretaceous and Tertiary non-marine sediments and igneous rocks (Fig. 2b); Middle Cretaceous Hayang group sediments, Late Cretaceous Yucheon group rocks, Early Miocene Yeonil group rocks, Middle Miocene Janggi group, and Bulguksa group granitic rocks which intruded the Cretaceous rocks during the Late Cretaceous to Early Tertiary (Chang, 1975, 1977, 1978;Chang et al., 1990). The lithology of each stratigraphic unit as documented in detail by the Korea Institute of Geoscience and Mineral Resources (KIGAM) can be briefly characterized as follows; the Hayang group is mostly composed of clastic sedimentary rocks including shale, mudstone, and sandstone with mafic or intermediate volcanic rocks. The Yucheon group consists of andesitic rocks and quartz andesites including plagioclase phenocrysts. The Yeonil group and Janggi group consist of Early and Middle Miocene sedimentary and volcanic rocks that are 'mainly exposed in the eastern part of the Gyeongsang Basin. The Yeonil group basin consists of a tuffaceous Tertiary sedimentary basin, and Miocene basal conglomeratic rocks, which consist

171 of light brown to light gray conglomerate and sandstone. The Janggi group rocks mainly 
consist of basaltic tuff and andesitic tuff of Early Miocene age. The Bulguksa intrusive rocks

173 are mainly composed of biotite granites accompanying grano-diorite, tonalite, and alkalidivided the bedrock aquifer well locations into four areas; (i) Hayang-group shale and sandstone (KW 1, KW 2, KW 9-2, KW 10-2), (ii) Bulguksa-group biotite granite (KW 3, KW 5-2, KW 12-2), (iii) tuff and tuffaceous sedimentary rocks of Yeonil-group and Janggi group (KW 4-2, KW 6-2, KW 7-2), and (iv) Cretaceous volcanic rocks mainly composed of andesite (KW 8-2, KW 11-2).

\section{Methods \& materials}

\section{Water sampling and analysis method}

Continuous monitoring data for water level, temperature, and electrical conductivity (EC), from the National Groundwater Monitoring Network (NGMN) of the Korea Water Resources Corporation, were analyzed (http://www.gims.go.kr). These daily data, which correspond to the average of the values measured every hour, were used for observing the responses before, during, and after the earthquake. Precipitation data obtained from the Korea Meteorological Administration were also analyzed with the water level variation (http://kma.go.kr). 

using a Grundfos MP-1 pump. The samples were analyzed for hydrochemical parameters, major ions, radon concentration, and strontium isotopes. The hydrochemical parameters temperature, EC, dissolved oxygen (DO), total dissolved solids (TDS), pH, and salinity were measured in the field using an YSI ProDSS digital sampling system (Xylem, USA). The analysis of cations and anions $\left(\mathrm{Na}, \mathrm{K}, \mathrm{Ca}, \mathrm{Mg}, \mathrm{Cl}, \mathrm{NO}_{3}, \mathrm{SO}_{4}\right.$, and $\left.\mathrm{HCO}_{3}\right)$. including strontium isotopes, was completed using filtered water samples at the Korea Basic Science Institute (KBSI). ${ }^{87} \mathrm{Sr} /{ }^{86} \mathrm{Sr}$ ratios were obtained using a Neptune Multicollector-Inductively Coupled Plasma Mass Spectrometer (MC-ICP-MS; Thermo Finnigan, Germany) upgraded with a large dry interface pump. Yields were approximately $100 \%$ and the matrix concentration did not exceed $1 \%$ of the strontium concentrations. The total procedural blanks were negligible with less than $1 \mathrm{ng}$ of $\mathrm{Sr}$. The ${ }^{87} \mathrm{Sr} /{ }^{86} \mathrm{Sr}$ ratios were normalized to ${ }^{86} \mathrm{Sr} /{ }^{88} \mathrm{Sr}=0.1194$ (Faure, 1986), and the mean ${ }^{87} \mathrm{Sr} /{ }^{86} \mathrm{Sr}$ ratio of NBS987 (U.S. National Bureau of Standards) was $0.710247 \pm$ $0.000017(2 \sigma, \mathrm{n}=18)$. The radon concentrations in the groundwater samples were measured using RTM1688-2 of SARAD. An air-bubbling 500-ml flask was filled with sampled water and connected to the monitor for a closed air loop. The measurement was conducted at 15min intervals. The attained values were calibrated adjusting for the short half-life of radon. The unit offers a high sensitivity of better than $3 \mathrm{cpm} /\left(\mathrm{kBq} / \mathrm{m}^{3}\right)$ obtained from a very small internal volume of only $130 \mathrm{ml}$. 
211 Self-Organizing Map (SOM) analysis is a neural network organized on a low-dimensional

212 array of processing units (Kohonen, 1982). The SOM consists of two layers: the input layer

213 and the output layer (neurons layer). These two layers are interconnected via a weight vector.

214 The neurons in the output layer are connected to adjacent neurons by a neighborhood relation

215 dictating the structure of the topographic map. In this study, the layer of neurons was

216 arranged onto a two-dimensional grid. The SOM is an unsupervised learning algorithm

217 without prior information of classification. The learning algorithm procedure can be

218 described as follows: (i) determine the number of neurons, (ii) initialize the weight vectors

219 with small random values, (iii) choose the best-matching neurons or the best-matching unit

220 (BMU) that is the closest to the input vector, and (iv) update the best-matching neurons and

221 neighboring neurons. The results can be visualized using two different types of map: the component planes and the U-matrix (Vesanto, 1999). The component plane representation visualizes relative component values of the weight vectors, providing correlations between components. The U-matrix, i.e. the unified distance matrix, enables clustering analysis using the distance between the weight vectors and their neighborhood. The simulation was 
There are few studies using SOM for groundwater quality data interpretation (Choi et al., 2014;Hong and Rosen, 2001;Lischeid, 2008). However, we used the SOM analysis for statistical analysis in the Gyeongju area because it can solve linear dimensionality reduction problems without biases. The contribution map of the variables is shown in the component map (Fig. 3). The dataset contained data regarding 16 variables ( $\mathrm{Na}, \mathrm{K}, \mathrm{Ca}, \mathrm{Mg}, \mathrm{Cl}, \mathrm{NO}_{3}, \mathrm{SO}_{4}$, $\mathrm{HCO}_{3}, \mathrm{Sr},{ }^{87} \mathrm{Sr} /{ }^{86} \mathrm{Sr}$, temperature, $\mathrm{pH}, \mathrm{DO}, \mathrm{EC}, \mathrm{TDS}$, and salinity) (Table 3). The values were used in a normalization form, not raw data. The normalization 'var', a simple linear transformation, was used with the variance of the variable to unity and its mean to zero. By comparing component planes, the planes of $\mathrm{Ca}, \mathrm{SO}_{4}, \mathrm{Sr}$, and ${ }^{87} \mathrm{Sr} /{ }^{86} \mathrm{Sr}$ have similar distributions, indicating a strong correlation between these variables. The $\mathrm{Na}, \mathrm{Cl}, \mathrm{HCO}_{3}, \mathrm{EC}$, TDS, and salinity values also had similar patterns to each other. These variables show vertical symmetry with the planes of $\mathrm{Ca}, \mathrm{SO}_{4}, \mathrm{Sr}$, and ${ }^{87} \mathrm{Sr} /{ }^{86} \mathrm{Sr}$. The components of temperature, $\mathrm{pH}$, DO, $\mathrm{K}$, and $\mathrm{NO}_{3}$ are distinct from each other, showing no relationship with the other variables.

The clustering could be investigated with the visual inspection of the U-matrix result (Fig. 4). Brown shades on the U-matrix indicate a large distance between neighborhood nodes whereas white shades correspond to a short distance between nodes. Based on the distances, the distribution of water samples could be classified into four groups: Group 1 (KW 1, KW 2, KW 9-1, and KW 10-1), Group 2 (KW 3, KW 5-1, KW 5-2, KW 6-2, KW 11-3, and KW 12 1), Group 3 (KW 4-1 and KW 4-2), and Group 4 (KW 8-1, KW 11-1, and KW 11-2). This 
classification has similar results with the classification based on lithostratigraphic unit data.

251 Group 1 has relatively high values of $\mathrm{Ca}, \mathrm{Mg}, \mathrm{SO}_{4}, \mathrm{NO}_{3}, \mathrm{Sr}$, and ${ }^{87} \mathrm{Sr} /{ }^{86} \mathrm{Sr}$. Group 2 falls between Group 3 and Group 4. Group 3 is characterized by distinctly high values in $\mathrm{K}, \mathrm{Na}, \mathrm{Cl}$,

$253 \mathrm{HCO}_{3}, \mathrm{EC}$, TDS, and salinity. Group 4 has high DO values and a distinct low temperature

254 and ${ }^{87} \mathrm{Sr} /{ }^{86} \mathrm{Sr}$ with relatively low values of EC, TDS, salinity, and $\mathrm{Sr}$.

\title{
4.2 Water level, temperature, and EC changes
}

\author{
Groundwater level changes in seven monitoring wells can be classified into three types: (i)
} no change related to the earthquake ( $\mathrm{KW} \mathrm{5-1} \mathrm{and} \mathrm{KW} 5-2$ ), (ii) maintenance after an instantaneous increase or decrease ( $\mathrm{KW} \mathrm{8-1,} \mathrm{KW} \mathrm{8-2,} \mathrm{and} \mathrm{KW} \mathrm{11-2),} \mathrm{and} \mathrm{(iii)} \mathrm{recovery} \mathrm{to}$ original values after a sudden change (KW 11-1) (Fig. 5). The groundwater level of the KW 5 wells did not change regardless of earthquake and precipitation (Fig. 5a). At the KW 8 wells, there was an abrupt increase during the earthquake and maintenance after the earthquake, particularly in the bedrock aquifer well (KW 8-2) (Fig. 5b). The groundwater level response to the earthquake in the alluvial aquifer well was in contrast to that in the bedrock aquifer well at the KW 11 wells (Fig. 5c). The groundwater level of KW 11-1 slightly increased before the earthquake and then decreased. However, the groundwater level of KW 11-2 drastically decreased and then gradually recovered and it remained at higher values compared to the original values.

Groundwater temperature changes only occurred at the KW 11 wells (Fig. 6a). These also 
showed an opposite change pattern, in which the groundwater temperature of $\mathrm{KW} 11-1$ recovered to the original value after an instantaneous increase, whereas that of KW 11-2 recovered after a slight decrease. This anomaly was apparent in the alluvial aquifer well (KW 11-1), unlike the groundwater level anomaly.

A change in groundwater ECs was observed at eight monitoring wells before, during, or after the earthquake. KW 1 responded to the earthquake in a peak form and gradually recovered. KW 2 showed an increase prior to the earthquake and recovered to original values. The groundwater EC consistently decreased and then remained at lower values at KW 6-1, KW 6-2, and KW 10-2. The peak form of the KW 11 wells also indicated an opposite direction (Fig. 6b). KW 11-1 peaked at a higher level several times prior to the earthquake, while KW 11-2 peaked at a lower level before the earthquake and then recovered. Compared to the water level data, however, it was difficult to interpret that the changes in EC could be attributed to the earthquake.

\subsection{Radon -222}

The distribution of radon concentration in the 21 groundwater samples is shown in Fig. 7. The radon concentration ranged from $225 \mathrm{~Bq} / \mathrm{m}^{3}$ to $23060 \mathrm{~Bq} / \mathrm{m}^{3}$ in the Gyeongju area (see Table 3). The KW 5-1, KW 5-2, and KW 8-2 values were 15849,17575 , and $23060 \mathrm{~Bq} / \mathrm{m}^{3}$, respectively, which were higher values than those of the other groundwater wells. These wells are near the epicenter. Lower values $(<1000 \mathrm{~Bq} / \mathrm{m} 3)$ were found in KW6-1, KW 6-2, KW 7- 

than the bedrock aquifer well.

\subsection{Strontium isotopes}

The strontium isotopic compositions of groundwater samples in the Gyeongju area are shown in Fig. 8. Strontium concentrations ranged from $18.1 \mathrm{ppb}$ to $4052 \mathrm{ppb}$. The ${ }^{87} \mathrm{Sr} /{ }^{86} \mathrm{Sr}$ values ranged from 0.7057 to 0.7124 (see Table 3). In the alluvial aquifer wells, the ${ }^{87} \mathrm{Sr} /{ }^{86} \mathrm{Sr}$ values ranged from 0.7061 to 0.7083 , and these values were from 0.7057 to 0.7124 in the bedrock aquifer wells. The strontium isotopic compositions of the groundwater samples also reflected distinct ratios based on their lithology and stratigraphy. The Hayang group (KW 1,

KW 2, KW 9-2 and KW 10-2) had high strontium concentrations. The ${ }^{87} \mathrm{Sr} /{ }^{86} \mathrm{Sr}$ values of the Bulguksa group (KW 3, KW 5-2, and KW 12-2) ranged from 0.706 to 0.708 . Cretaceous volcanic rocks (KW 8-2 and KW 11-2) are below the Bulguksa group. The KW 6 wells had distinct characteristics, in which KW 6-1 was far from KW 6-2.

The spatial distributions of strontium concentrations and ${ }^{87} \mathrm{Sr} /{ }^{86} \mathrm{Sr}$ are shown in Fig. 9. 
11-1 had significantly low values (< $100 \mathrm{ppb})$. The wells that had high strontium concentrations were in the Hayang group. For the ${ }^{87} \mathrm{Sr} /{ }^{86} \mathrm{Sr}$ results, KW 1, KW 2, KW 6-2, KW 10-2, and KW 11-2 had high ratio values, while KW 3, KW 6-1, KW 7-1, KW 8-2, and KW 11-1 had low ratio values. The values between the alluvial and bedrock aquifer wells were quite different in KW 6, KW 8, KW 10, and KW 11.

Calcium and strontium cation contents of the groundwater samples showed various distributions, ranging from $1.59 \mathrm{mg} / \mathrm{L}$ to $94.89 \mathrm{mg} / \mathrm{L}$ for calcium and from $18.1 \mathrm{ppb}$ to 4052 ppb for strontium concentration (Fig. 10). The positive relationship between $\mathrm{Sr}$ and $\mathrm{Ca}$ is consistent with the chemical similarity of strontium and calcium, reflecting similar behavior in both rock and groundwater. The $\mathrm{Sr}^{2+}$ cation contents of the Hayang group ranged from 18.1 ppb to $4052 \mathrm{ppb}$, which was much higher than the values generally measured in groundwater as hundreds of ppb (Frost and Toner, 2004;Santoni et al., 2016).

\section{Discussion}

The Gyeongju earthquake on September 12, 2016, remarkably affected the groundwater systems. The total data showing anomalies are shown in Table 4. The groundwater level, temperature, and EC data were analyzed considering pre-, co-, and post-seismic changes. For the groundwater level data, three anomaly types were observed (see Fig. 5). Among them, the maintenance of a groundwater level increase could be attributed to aquifer compaction (as 
observed in KW 8-1 and KW 8-2) (Lee et al., 2002). There is a possibility that the aquifers underwent non-recoverable deformation. The persistent groundwater level changes also have been influenced by volumetric strain changes (Matsumoto et al., 2003;Roeloffs et al., 2003; Wang et al., 2007). In contrast, a greater decrease in groundwater level prior to the earthquake could be attributed to the opening of bedrock fractures (as observed in KW 11-1) (Fleeger et al., 1999;Rojstaczer and Wolf, 1992;Rojstaczer et al., 1995). A decrease could also possibly be related to a change in permeability (Brodsky, 2003;Manga and Wang, 2007). Groundwater level oscillation also depends on the interaction between the flow in the well and the flow into and out of the aquifer (Cooper et al., 1965). There is another anomaly, an opposite change pattern between the alluvial and bedrock aquifer wells, as observed in all datasets of groundwater level, temperature, and EC data for KW 11. This means that the two wells had weak interactions with each other.

Isotopic data including radon and strontium were collected only after earthquake. A difference in radon concentration between the alluvial and bedrock aquifer wells could be considered more significant because of the mixing effect as observed in KW 8 and KW 11. Seismotectonic activity may often change the mixing ratio of groundwater in a well (Hartmann and Levy, 2005). The anomaly in which the alluvial aquifer well had a higher radon concentration than that of the bedrock aquifer could be attributed to rainfall; however, in this area, rainfall did not occur during the sampling period (as observed in KW 7, KW 9, and KW 11). The large variation in the ${ }^{87} \mathrm{Sr} /{ }^{86} \mathrm{Sr}$ ration in the groundwater can consequently 
largely be explained by the nature of the aquifer lithology. For example, the high $\mathrm{Rb} / \mathrm{Sr}$ ratio of composite silicate minerals such as plagioclase, feldspar, and biotite can cause granitic bedrock to be highly radiogenic (Frost and Toner, 2004;Santoni et al., 2016). Generally, the Bulguksa granite had a strontium concentration from $62 \mathrm{ppm}$ to $428 \mathrm{ppm}$ and an ${ }^{87} \mathrm{Sr} /{ }^{86} \mathrm{Sr}$ ratio from 0.7046 to 0.7114 (Cheong and Jo, 2017). Basaltic rocks near the Yeonil group and Janggi group had strontium concentration from $439 \mathrm{ppm}$ to $518 \mathrm{ppm}$ and an ${ }^{87} \mathrm{Sr} /{ }^{86} \mathrm{Sr}$ ratio from 0.7039 to 0.7046 (Shimazu et al., 1990). In the Chaeyaksan basaltic volcanics of the Yucheon group, strontium concentration ranged from $731 \mathrm{ppm}$ to $1667 \mathrm{ppm}$ and the ${ }^{87} \mathrm{Sr} /{ }^{86} \mathrm{Sr}$ ratio from 0.7059 to 0.7064 (Yun, 1998). Thus, the more radiogenic samples of the Bulguksa granite were expected compared to those of the Yucheon group rocks, because of the high biotite content of the Bulguksa granite.

The most significant and novel result from this study is that these responses were analyzed with the result of grouping conducted using the SOM statistic tool. The SOM results were in agreement with the lithostratigraphic unit data which was useful in arranging the bedrock aquifer wells, based on bedrock characteristics. The final grouping yielded four classes of wells: Group A (KW 1, KW 2, KW 9, and KW 10); Group B (KW 3, KW 5, and KW 12); Group C (KW 4, KW 6, and KW 7); and Group D (KW 8 and KW 11). This grouping was conducted as one well binding the alluvial and bedrock aquifer wells. 
of low porosity and high strontium concentrations. Particularly, the KW 9 and the KW 10 wells had a low radon concentration $(<1000 \mathrm{~Bq} / \mathrm{m} 3)$, high strontium concentration, and high Ca value (see Fig. 10). There might be some possible mechanisms for the exceptionally strong chemical signatures. Regarding earthquakes, first, the fine-grained bedrock of Group A has a large reactive surface area that can effectively activate water-rock interaction and largely vary the groundwater chemistry via ion exchange (Pennisi et al., 2006). These interactions can cause high strontium concentrations. Second, particularly for KW10-2 in Group A, the exceptionally high $\mathrm{Sr}$ samples appear to be an effect of cation exchange between the soil and surrounding water. The capacity of the cation-bearing soil (cationexchange capacity; CEC) depends on the $\mathrm{pH}$ of the surrounding water, and $\mathrm{Ca}^{2+}$ and $\mathrm{Sr}^{2+}$ are characterized by particularly high replaceability (Carroll, 1959). The acidic water of KW 10$2(\mathrm{pH}=2.27)$ would lead to a lower CEC in the soil and dissolution of $\mathrm{Ca}^{2+}$ and $\mathrm{Sr}^{2+}$ from the soil grain surface as hydrogen ions replace $\mathrm{Ca}$ and $\mathrm{Sr}$ in the soil. The flow into the groundwater in the Hayang group rocks could increase the chemical concentration of Group A. Third, the results could be attributed to geological characteristics, not related to the earthquake, as the intrinsic chemistry of the Hayang group shale and sandstone might affect the strontium concentrations. Such dramatically high values of Sr were previously observed in the Redbeds aquifer (885-7851 ppb) where the lithology of the bedrock is composed of shale and sandstone with high $\mathrm{Rb} / \mathrm{Sr}$ ratios (Santoni et al., 2016).

Group B wells are located in a granitic biotite region of the Bulguksa group, which has a 
typical high radon concentration. The radon concentration is greatly influenced by uranium content; thus, its concentration is generally high in granite compared to that of sedimentary rocks. Typically, uranium concentration is high in granites, whereas it is low in sedimentary rocks. However, only the KW 5 wells had a high radon concentration. In particular, KW 5-1 had high values similar to those of KW 5-2. This could be attributed to deep fluid upwelling from the bedrock in the KW 5 wells (Chiodini et al., 2000;Minissale, 2004;Savoy et al., 2011). However, it is difficult to confidently determine an effect of upwelling because data were only collected after the earthquake, not prior.

Group C is composed of tuff and tuffaceous sedimentary rocks of the Yeonil and Janggi groups. This group had a low radon concentration and a small difference in radon concentration between the alluvial and the bedrock aquifer wells (see Fig. 7), suggesting active water mixing between the two aquifers. In addition, the bedrock of this area contains conglomerates, which generally have high pore density, leading to active mixing with water compared to the shale-dominant lithology. This hypothesis seems to be consistent with the weak chemical signature of Group A. Moreover, KW 4-1, KW 4-2, and KW 6-2 had high values of $\mathrm{EC}$ and $\mathrm{Cl}$, suggesting the possibility of sea water intrusion in the wells. Sea water intrusion might actively trigger mixing between the shallow and deep aquifers. The strontium concentration and Ca values are also low in these wells (see Fig. 10).

In Group D, the radon concentration was quite different between the two wells and a 
groundwater level anomaly occurred (see Fig. 7). The wells of this group are in Cretaceous mainly andesitic volcanic rocks. The KW 11 wells, in particular, showed many factors including groundwater level, temperature, and EC responded to the earthquake in an opposite manner (see Fig. 5 and Fig. 6). The radon concentration of KW 11-1 was also higher than that of KW 11-2. The Sr contents of Group B and Group D show a wide range of concentrations observed in other studies of groundwater in the granitic bedrock aquifers; e.g., an $\mathrm{Sr}^{2+}$ from 67 to 169 ppb (Frost and Toner, 2004) and from 103 to 553 ppb (Santoni et al., 2016). This wide range might be associated with the different amount of plagioclase feldspar in each matrix rock of the groundwater. Water flow via granite can be controlled by the dissolution of anorthite and alkali feldspar. The former occurs more rapidly, providing $\mathrm{Ca}^{2+}$ and $\mathrm{Sr}^{2+}$ with a low ${ }^{87} \mathrm{Sr} /{ }^{86} \mathrm{Sr}$ ratio (Bullen et al., 1997;Franklyn et al., 1991). In contrast, one groundwater chemistry study in Canada showed that dissolution of alkali feldspar can increase the ${ }^{87} \mathrm{Sr} /{ }^{86} \mathrm{Sr}$ ratio providing sodium and potassium (Bullen et al., 1996). Therefore, the various compositions of the granite and the fluid mobility would be determinative in the ${ }^{87} \mathrm{Sr} /{ }^{86} \mathrm{Sr}$ ratio.

In accordance with this analysis, conceptual models of groundwater changes induced by the earthquakes can be suggested (Fig. 11). Four different models were inferred by data analysis and the grouping result using the SOM approach. First, a response highlighting the mixing with deep groundwater or bedrock can be attributed to a deep fluid rise, which resulted in high strontium concentrations, as observed in the wells of Group A (KW 1 and KW 2). In 
addition, low radon values and high ${ }^{87} \mathrm{Sr} /{ }^{86} \mathrm{Sr}$ ratios were observed in the wells of the alluvial aquifer, KW 9-1 and KW 10-1. Second, the possibility of non-recoverable deformation after deep fluid upwelling can be suggested as there was no change in water level and there were high radon concentrations in both wells of the alluvial and bedrock aquifers (KW 5-1 and KW 5-2) in Group B. This hypothesis can be supported by studies showing that the stress reduction after an earthquake causes closure of cracks (Nur and Booker, 1972;Scholz et al., 1973). The other wells of Group B could be classified as an uninfluenced by the earthquakes. Third, another mechanism, the strong interaction between shallow and deep aquifers, can be attributed to sea water intrusion by the data showing a small difference in radon concentration between the alluvial and the bedrock aquifer wells, as observed in Group C. Finally, the response to the movement of the strike-slip fault can be explained considering the location of Group D, which is near the YSF. The water level anomaly suggests the potential that the source of the alluvial aquifer well changed a different source compared to that of bedrock aquifer well after the earthquakes (see Fig 5). Bedrock fracture opening could cause a decrease in water level, suggesting that surrounding aquifer affected the alluvial aquifer of these wells because of the difference in water level, as observed in KW 11-2. In contrast, the groundwater level appeared to remain constant at a higher value than the pre-earthquake value via aquifer compaction because of the movement of the strike-slip fault at the KW 8 wells. 
Hydrol. Earth Syst. Sci. Discuss., https://doi.org/10.5194/hess-2018-360

Manuscript under review for journal Hydrol. Earth Syst. Sci.

Discussion started: 7 August 2018

(c) Author(s) 2018. CC BY 4.0 License.

hydrogeological characterizations because of the limited dataset. Further monitoring or

445

446

modeling works will help to reinforce the proposed model.

\section{Conclusion}

The 2016 Gyeongju earthquakes affected the pre-, co-, and post-earthquake groundwater systems. Changes were observed in groundwater level, temperature, EC, hydrochemistry, radon-222, and strontium isotopic data. The main findings obtained via data analysis from 21 monitoring wells are as follows:

1. The observed groundwater level anomaly could be attributed to pre-earthquakes effect, not a seasonal effect. Maintenance, persistent or abrupt changes, and oscillation of water levels were observed in some wells.

2. The radon concentration could be interpreted as the difference between alluvial and bedrock aquifer wells. A relatively small difference between two radon values implies active mixing processes between the shallow and deep aquifers.

3. Strontium isotopes were interpreted with the lithology and stratigraphy of bedrock, indicating the potential of water-rock interactions. These isotopes $\left(\mathrm{Sr}^{2+}\right.$ concentrations and ${ }^{87} \mathrm{Sr} /{ }^{86} \mathrm{Sr}$ ratio) also could suggest both geologically independent causes and dependent causes with respect to the earthquakes. 
Hydrol. Earth Syst. Sci. Discuss., https://doi.org/10.5194/hess-2018-360

Manuscript under review for journal Hydrol. Earth Syst. Sci.

Discussion started: 7 August 2018

4. The SOM statistic tool was found to be useful for identifying each group having common characteristics and the influence of the earthquakes on hydrogeochemical parameters. The final grouping can explain the possible mechanisms via different hydrogeochemical processes: (i) water-rock interactions because of deep fluid rising, (ii) no response to the earthquakes or non-recoverable deformation after the earthquake, (iii) aquifer mixing vertically due to sea water intrusion, and (iv) the effect of the movement of the strike-slip fault.

These results can have significant impact on regional and national Authorities, because seismicity has increased in the area near Gyeongju since 2016. It may be more helpful in efficiently managing groundwater systems to analyze the combined hydrogeochemical and lithostratigraphic characteristics of the area. In addition, the studied parameters and the adopted methods would be positively applied for other earthquake zones, particularly for grouping interpretation of response of monitoring wells.

\section{Data availability}

The dataset for water level, temperature, and electrical conductivity presented in this paper is available online at http://www.gims.go.kr. The precipitation data is available at http://kma.go.kr. 
Hydrol. Earth Syst. Sci. Discuss., https://doi.org/10.5194/hess-2018-360

Manuscript under review for journal Hydrol. Earth Syst. Sci.

Discussion started: 7 August 2018

(c) Author(s) 2018. CC BY 4.0 License.

\section{Author contribution}

482

483
J. Kim and K.K. Lee had the idea and supervised this paper. J. Lee wrote the geological setting of the study area and drew some figures. M.P. discussed the results and contributed to writing the paper. All authors designed sampling method and analyzed the samples.

\section{Competing interests}

The authors declare that they have no conflict of interest. 
Hydrol. Earth Syst. Sci. Discuss., https://doi.org/10.5194/hess-2018-360

$\begin{array}{r}\text { Hydrology and } \\ \text { Earth System } \\ \text { Sciences } \\ \hline \text { Discussions }\end{array}$

Manuscript under review for journal Hydrol. Earth Syst. Sci.

Discussion started: 7 August 2018

(c) Author(s) 2018. CC BY 4.0 License.

(c) (i)

497

Acknowledgments.

498

This work was supported by the National Research Foundation of Korea (NRF) grant funded

499

by the Korea government(MSIP) (No. 2017R1A2B3002119)

500

501

502

503

504

505

506

507

508

509

510

511 
Adinolfi Falcone, R., Carucci, V., Falgiani, A., Manetta, M., Parisse, B., Petitta, M., Rusi, S.,

515 Spizzico, M., and Tallini, M.: Changes on groundwater flow and hydrochemistry of the Gran

516 Sasso carbonate aquifer after 2009 L'Aquila earthquake, Italian Journal of Geosciences, 131,

$517 \quad 459-474,2012$.

518 Amoruso, A., and Crescentini, L.: Limits on earthquake nucleation and other pre-seismic

519 phenomena from continuous strain in the near field of the 2009 L'Aquila earthquake,

520 Geophysical Research Letters, 37, n/a-n/a, 10.1029/2010g1043308, 2010. L'Aquila earthquake on groundwater flow in the Gran Sasso carbonate aquifer, Central Italy, Hydrological Processes, 25, 1754-1764, 10.1002/hyp.7933, 2011. changes before and during the 2016 Amatrice-Norcia seismic sequence (central Italy), Scientific Reports, 7, 11735, 10.1038/s41598-017-11990-8, 2017. heterogeneous planar fault zone, Bulletin of the Seismological Society of America, 80, 971994, 1990.

Brodsky, E. E.: A mechanism for sustained groundwater pressure changes induced by distant

531 earthquakes, Journal of Geophysical Research, 108, 10.1029/2002jb002321, 2003. chronosequence on granitoid alluvium: II. Mineralogic and isotopic constraints on the behavior of strontium, Geochimica et Cosmochimica Acta, 61, 291-306, 1997. 
Wisconsin, USA, Geochimica et Cosmochimica Acta, 60, 1807-1821, 1996.

Carroll, D.: Ion exchange in clays and other minerals, Geological Society of America Bulletin, 70, 749-779, 1959.

Chang, C., Lee, J. B., and Kang, T.-S.: Interaction between regional stress state and faults: Complementary analysis of borehole in situ stress and earthquake focal mechanism in southeastern Korea, Tectonophysics, 485, 164-177, 2010.

Chang, K.-H., Woo, B.-G., Lee, J.-H., Park, S.-O., and Yao, A.: Cretaceous and Early Cenozoic Stratigraphy and History of Eastern Kyŏngsang Basin, S. Korea, Journal of the Geological Society of Korea, 26, 471-487, 1990.

Chang, K.: Cretaceous stratigraphy of southeast Korea, Journal of the Geological Society of Korea, 11, 1-23, 1975.

Chang, K.: Late Mesozoic stratigraphy, sedimentation and tectonics of southeastern Korea, Journal of the Geological Society of Korea, 13, 76-79, 1977.

Chang, K.: Late Mesozoic stratigraphy, sedimentation and tectonics of southeastern Korea (11) - with discussion on petroleum possibility, Journal of the Geological Society of Korea, 14, $120-135,1978$.

Cheong, A. C.-S., and Jo, H. J.: Crustal evolution in the Gyeongsang Arc, southeastern Korea: Geochronological, geochemical and Sr-Nd-Hf isotopic constraints from granitoid rocks, American Journal of Science, 317, 369-410, 2017.

Chiodini, G., Frondini, F., Cardellini, C., Parello, F., and Peruzzi, L.: Rate of diffuse carbon dioxide Earth degassing estimated from carbon balance of regional aquifers: The case of central Apennine, Italy, Journal of Geophysical Research: Solid Earth, 105, 8423-8434, 10.1029/1999jb900355, 2000.

Choi, B.-Y., Yun, S.-T., Kim, K.-H., Kim, J.-W., Kim, H. M., and Koh, Y.-K.: Hydrogeochemical interpretation of South Korean groundwater monitoring data using Self- 
Hydrol. Earth Syst. Sci. Discuss., https://doi.org/10.5194/hess-2018-360

Manuscript under review for journal Hydrol. Earth Syst. Sci.

Discussion started: 7 August 2018

(c) Author(s) 2018. CC BY 4.0 License.
Hydrology and

Earth System

Sciences

Discussions
562

563

564

565

566

567

568

569

570

571

Organizing Maps, Journal of Geochemical Exploration, 137, 73-84, 10.1016/j.gexplo.2013.12.001, 2014.

Claesson, L., Skelton, A., Graham, C., and MÖRTH, C. M.: The timescale and mechanisms of fault sealing and water-rock interaction after an earthquake, Geofluids, 7, 427-440, 2007.

Cooper, H. H., Bredehoeft, J. D., Papadopulos, I. S., and Bennett, R. R.: The response of well-aquifer systems to seismic waves, Journal of Geophysical Research, 70, 3915-3926, 1965.

Ekemen Keskin, T.: Groundwater changes in relation to seismic activity: a case study from Eskipazar (Karabuk, Turkey), Hydrogeology Journal, 18, 1205-1218, 10.1007/s10040-0100589-x, 2010.

Faure, G.: Principles of isotope geology, 1986.

Fitz-Diaz, E., Hudleston, P., Siebenaller, L., Kirschner, D., Camprubí, A., Tolson, G., and Puig, T. P.: Insights into fluid flow and water-rock interaction during deformation of carbonate sequences in the Mexican fold-thrust belt, Journal of Structural Geology, 33, 1237 $1253,2011$.

Fleeger, G. M., Goode, D. J., Buckwalter, T. F., and Risser, D. W.: Hydrologic effects of the Pymatuning earthquake of September 25, 1998, in northwestern Pennsylvania, 4170, US Department of the Interior, US Geological Survey, 1999.

Franklyn, M., McNutt, R., Kamineni, D., Gascoyne, M., and Frape, S.: Groundwater 87Sr/86Sr values in the Eye-Dashwa Lakes pluton, Canada: Evidence for plagioclase-water reaction, Chemical Geology: Isotope Geoscience Section, 86, 111-122, 1991.

Frape, S., Fritz, P., and McNutt, R. t.: Water-rock interaction and chemistry of groundwaters from the Canadian Shield, Geochimica et Cosmochimica Acta, 48, 1617-1627, 1984.

Frost, C. D., and Toner, R. N.: Strontium isotopic identification of water-rock interaction and ground water mixing, Groundwater, 42, 418-432, 2004. 
Galassi, D. M., Lombardo, P., Fiasca, B., Di Cioccio, A., Di Lorenzo, T., Petitta, M., and Di Carlo, P.: Earthquakes trigger the loss of groundwater biodiversity, Scientific Reports, 4, 6273, 10.1038/srep06273, 2014.

Ghosh, A., Vidale, J. E., Sweet, J. R., Creager, K. C., and Wech, A. G.: Tremor patches in Cascadia revealed by seismic array analysis, Geophysical Research Letters, 36, 10.1029/2009g1039080, 2009.

Gray, D. R., Gregory, R. T., and Durney, D. W.: Rock-buffered fluid-rock interaction in deformed quartz-rich turbidite sequences, eastern Australia, Journal of Geophysical Research: Solid Earth, 96, 19681-19704, 1991.

Hartmann, J., and Levy, J. K.: Hydrogeological and gasgeochemical earthquake precursors-A review for application, Natural Hazards, 34, 279-304, 2005.

Heidbach, O., Tingay, M., Barth, A., Reinecker, J., Kurfeß, D., and Müller, B.: Global crustal stress pattern based on the World Stress Map database release 2008, Tectonophysics, 482, 3$15,2010$.

Hoehn, E., and Von Gunten, H.: Radon in groundwater: A tool to assess infiltration from surface waters to aquifers, Water Resources Research, 25, 1795-1803, 1989.

Hong, T. K., Lee, J., Kim, W., Hahm, I. K., Woo, N. C., and Park, S.: The 12 September 2016 ML5. 8 midcrustal earthquake in the Korean Peninsula and its seismic implications, Geophysical Research Letters, 44, 3131-3138, 2017.

Hong, Y.-S., and Rosen, M. R.: Intelligent characterisation and diagnosis of the groundwater quality in an urban fractured-rock aquifer using an artificial neural network, Urban Water, 3, 193-204, 2001.

Hwang, B.-H., Lee, J.-D., Yang, K., and McWilliams, M.: Cenozoic strike-slip displacement along the Yangsan fault, southeast Korean Peninsula, International Geology Review, 49, 768$775,2007$. 
613 Fault: lateral displacement of the Yangsan Fault, Journal of the Geological Society of Korea, 40, 161-178, 2004.

Igarashi, G., Saeki, S., Takahata, N., Sumikawa, K., Tasaka, S., Sasaki, Y., Takahashi, M., and Sano, Y.: Ground-water radon anomaly before the Kobe earthquake in Japan, Science, 269, 60-61, 1995.

Jiang, L., Qiu, Z., Wang, Q., Guo, Y., Wu, C., Wu, Z., and Xue, Z.: Joint development and tectonic stress field evolution in the southeastern Mesozoic Ordos Basin, west part of North China, Journal of Asian Earth Sciences, 127, 47-62, 2016.

Kang, J.-H., and Ryoo, C.-R.: The movement history of the southern part of the Yangsan Fault Zone interpreted from the geometric and kinematic characteristics of the Sinheung Fault, Eonyang, Gyeongsang Basin, Korea, The Journal of the Petrological Society of Korea, 18, 19-30, 2009.

Kim, K. H., Kim, J., Han, M., Kang, S. Y., Son, M., Kang, T. S., Rhie, J., Kim, Y., Park, Y., and Kim, H. J.: Deep Fault Plane Revealed by High-Precision Locations of Early Aftershocks Following the 12 September 2016 ML 5.8 Gyeongju, Korea, Earthquake, Bulletin of the Seismological Society of America, 108, 517-523, 2017a.

Kim, Y., Jang, B.-A., and Park, S.: Open microcracks in granites from the Yangsan fault zone and the stress field of the Kyeongsang Basin, Journal of the Geological Society of Korea, 32, 367-378, 1996.

Kim, Y., and Jin, K.: Estimated earthquake magnitude from the Yugye Fault displacement on a trench section in Pohang, SE Korea, Journal of the Geological Society of Korea, 42, 79-94, 2006.

Kim, Y., Rhie, J., Kang, T.-S., Kim, K.-H., Kim, M., and Lee, S.-J.: The 12 September 2016 Gyeongju earthquakes: 1. Observation and remaining questions, Geosciences Journal, 20, 
$747-752,2016$.

Kim, Y., He, X., Ni, S., Lim, H., and Park, S. C.: Earthquake Source Mechanism and Rupture Directivity of the 12 September 2016 M w 5.5 Gyeongju, South Korea, Earthquake, Bulletin of the Seismological Society of America, 107, 2525-2531, $2017 \mathrm{~b}$.

King, C.-Y.: Radon emanation on San Andreas fault, Nature, 271, 516, 1978.

Kitagawa, Y., and Koizumi, N.: A study on the mechanism of coseismic groundwater changes: Interpretation by a groundwater model composed of multiple aquifers with different strain responses, Journal of Geophysical Research: Solid Earth, 105, 19121-19134, $10.1029 / 2000 j b 900156,2000$.

Kohonen, T.: Self-organized formation of topologically correct feature maps, Biological cybernetics, 43, 59-69, 1982.

Kyung, J., and Chang, T.: The latest fault movement on the northern Yangsan fault zone around the Yugye-ri area, southeast Korea, Journal of the Geological Society of Korea, 37, $563-577,2001$.

Kyung, J. B., and Lee, G. H.: A paleoseismological study of the Yangsan fault-analysis of deformed topography and trench survey, Journal of the Korean Geophysical Society, 2, 1999. Kyung, J. B.: Paleoseismology of the Yangsan fault, southeastern part of the Korean peninsula, Annals of Geophysics, 46, 983-996, 2003.

Kyung, J. B., and Lee, K.: Active fault study of the Yangsan fault system and Ulsan fault system, Southeastern part of the Korean Peninsula, Journal of Korean Geophysical Society, 9, 219-230, 2006.

Lee, J., Ryoo, Y., Park, S. C., Ham, Y. M., Park, J. S., Kim, M. S., Park, S. M., Cho, H. G., Lee, K. S., and Kim, I. S.: Seismicity of the 2016 ML 5.8 Gyeongju earthquake and aftershocks in South Korea, Geosciences Journal, 22, 1-12, 2018.

Lee, K., and Na, S. H.: A study of microearthquake activity of the Yangsan fault, Journal of 
Lee, K., and Jin, Y. G.: Segmentation of the Yangsan fault system: geophysical studies on major faults in the Kyeongsang basin, Journal of the Geological Society of Korea, 27, 434449, 1991.

Lee, M., Liu, T.-K., Ma, K.-F., and Chang, Y.-M.: Coseismic hydrological changes associated with dislocation of the September 21, 1999 Chichi earthquake, Taiwan, Geophysical Research Letters, 29, 5-1-5-4, 10.1029/2002g1015116, 2002.

Lee, S.-H., Ha, K., Hamm, S.-Y., and Ko, K.-S.: Groundwater responses to the 2011 Tohoku Earthquake on Jeju Island, Korea, Hydrological Processes, 27, 1147-1157, 10.1002/hyp.9287, 2013. Lischeid, G.: Non-linear visualization and analysis of large water quality data sets: a modelfree basis for efficient monitoring and risk assessment, Stochastic Environmental Research and Risk Assessment, 23, 977-990, 10.1007/s00477-008-0266-y, 2008.

Liu, K.-K., Yui, T.-F., Yeh, Y.-H., Tsai, Y.-B., and Teng, T.-L.: Variations of radon content in groundwaters and possible correlation with seismic activities in northern Taiwan, pure and applied geophysics, 122, 231-244, 1984.

Manga, M.: Origin of postseismic streamflow changes inferred from baseflow recession and magnitude-distance relations, Geophysical Research Letters, 28, 2133-2136, 10.1029/2000gl012481, 2001.

Manga, M., and Wang, C. Y.: Pressurized oceans and the eruption of liquid water on Europa and Enceladus, Geophysical Research Letters, 34, 10.1029/2007g1029297, 2007.

Manga, M., Beresnev, I., Brodsky, E. E., Elkhoury, J. E., Elsworth, D., Ingebritsen, S. E., Mays, D. C., and Wang, C.-Y.: Changes in permeability caused by transient stresses: Field observations, experiments, and mechanisms, Reviews of Geophysics, 50, 10.1029/2011rg000382, 2012. 
Matsumoto, N., Kitagawa, G., and Roeloffs, E.: Hydrological response to earthquakes in the Haibara well, central Japan-I. Groundwater level changes revealed using state space decomposition of atmospheric pressure, rainfall and tidal responses, Geophysical Journal International, 155, 885-898, 2003.

Minissale, A.: Origin, transport and discharge of CO2 in central Italy, Earth-Science Reviews, 66, 89-141, 10.1016/j.earscirev.2003.09.001, 2004.

Négrel, P., Giraud, E. P., and Widory, D.: Strontium isotope geochemistry of alluvial groundwater: a tracer for groundwater resources characterisation, Hydrology and Earth System Sciences Discussions, 8, 959-972, 2004.

Noguchi, M., and Wakita, H.: A method for continuous measurement of radon in groundwater for earthquake prediction, Journal of Geophysical Research, 82, 1353-1357, 1977.

Nur, A., and Booker, J. R.: Aftershocks caused by pore fluid flow?, Science, 175, 885-887, 1972.

Park, J. C., Kim, W., Chung, T. W., Baag, C. E., and Ree, J. H.: Focal mechanisms of recent earthquakes in the southern Korean Peninsula, Geophysical Journal International, 169, 1103$1114,2007$.

Park, Y., Ree, J.-H., and Yoo, S.-H.: Fault slip analysis of Quaternary faults in southeastern Korea, Gondwana Research, 9, 118-125, 2006.

Pennisi, M., Bianchini, G., Muti, A., Kloppmann, W., and Gonfiantini, R.: Behaviour of boron and strontium isotopes in groundwater-aquifer interactions in the Cornia Plain (Tuscany, Italy), Applied Geochemistry, 21, 1169-1183, 2006.

Petitta, M., Mastrorillo, L., Preziosi, E., Banzato, F., Barberio, M. D., Billi, A., Cambi, C., De Luca, G., Di Carlo, G., and Di Curzio, D.: Water-table and discharge changes associated with the 2016-2017 seismic sequence in central Italy: hydrogeological data and a conceptual model for fractured carbonate aquifers, Hydrogeology Journal, 1-18, 2018. 
713 Roeloffs, E., Sneed, M., Galloway, D. L., Sorey, M. L., Farrar, C. D., Howle, J. F., and

714 Hughes, J.: Water-level changes induced by local and distant earthquakes at Long Valley caldera, California, Journal of Volcanology and Geothermal Research, 127, 269-303, 10.1016/s0377-0273(03)00173-2, 2003.

Roeloffs, E. A.: Persistent water level changes in a well near Parkfield, California, due to local and distant earthquakes, Journal of Geophysical Research: Solid Earth, 103, 869-889, 10.1029/97jb02335, 1998.

Rojstaczer, S., and Wolf, S.: Permeability changes associated with large earthquakes: An example from Loma Prieta, California, Geology, 20, 211-214, 1992.

Rojstaczer, S., Wolf, S., and Michel, R.: Permeability enhancement in the shallow crust as a cause of earthquake-induced hydrological changes, Nature, 373, 237, 1995.

Celle-Jeanton, H.: Strontium isotopes as tracers of water-rocks interactions, mixing processes and residence time indicator of groundwater within the granite-carbonate coastal aquifer of Bonifacio (Corsica, France), Science of the Total Environment, 573, 233-246, 2016. Savoy, L., Surbeck, H., and Hunkeler, D.: Radon and CO2 as natural tracers to investigate the recharge dynamics of karst aquifers, Journal of Hydrology, 406, 148-157, 10.1016/j.jhydrol.2011.05.031, 2011. Science, 181, 803-810, 1973. applications to source characterisation and water-rock interaction in contrasting landscapes, Applied Geochemistry, 24, 574-586, 2009. 
following four great earthquakes - insights from co-seismic responses throughout the Chinese mainland, Earth and Planetary Science Letters, 430, 66-74, 10.1016/j.eps1.2015.08.012, 2015.

Shimazu, M., Kawano, Y., and Kagami, H.: Major and minor element compositions and Sr, $\mathrm{Nd}$ isotope ratios of basaltic rocks from the Pohang-Yangnam area, Korea, Journal of Mineralogy, Petrology and Economic Geology, 85, 405-415, 1990.

Son, M., Cho, C. S., Shin, J. S., Rhee, H. M., and Sheen, D. H.: Spatiotemporal Distribution of Events during the First Three Months of the 2016 Gyeongju, Korea, Earthquake Sequence, Bulletin of the Seismological Society of America, 108, 210-217, 2017.

Teng, T. L.: Some recent studies on groundwater radon content as an earthquake precursor, Journal of Geophysical Research: Solid Earth, 85, 3089-3099, 1980.

Tokunaga, T.: Modeling of earthquake-induced hydrological changes and possible permeability enhancement due to the 17 January 1995 Kobe Earthquake, Japan, Journal of Hydrology, 223, 221-229, 1999.

Torgersen, T., Benoit, J., and Mackie, D.: Controls on groundwater Rn-222 concentrations in fractured rock, Geophysical Research Letters, 17, 845-848, 1990.

Vesanto, J.: SOM-based data visualization methods, Intelligent data analysis, 3, 111-126, 1999.

Vesanto, J., and Alhoniemi, E.: Clustering of the self-organizing map, IEEE Transactions on neural networks, 11, 586-600, 2000.

Wakita, H., Nakamura, Y., Notsu, K., Noguchi, M., and Asada, T.: Radon anomaly: a possible precursor of the 1978 Izu-Oshima-kinkai earthquake, Science, 207, 882-883, 1980.

Walia, V., Lin, S. J., Hong, W. L., Fu, C. C., Yang, T. F., Wen, K. L., and Chen, C. H.: Continuous temporal soil-gas composition variations for earthquake precursory studies along Hsincheng and Hsinhua faults in Taiwan, Radiation Measurements, 44, 934-939, 
763 Wang, C.-Y., and Manga, M.: Hydrologic responses to earthquakes and a general metric,

764 Geofluids, 10.1111/j.1468-8123.2009.00270.x, 2010.

765 Wang, C.-y., Manga, M., Wang, C.-H., and Chen, C.-H.: Transient change in groundwater

766 temperature after earthquakes, Geology, 40, 119-122, 10.1130/g32565.1, 2012.

767 Wang, K., Hu, Y., Bevis, M., Kendrick, E., Smalley, R., Vargas, R. B., and Lauría, E.: Crustal motion in the zone of the 1960 Chile earthquake: Detangling earthquake-cycle deformation and forearc-sliver translation, Geochemistry, Geophysics, Geosystems, 8, n/a-n/a, 10.1029/2007gc001721, 2007.

Wang, K., and Fialko, Y.: Slip model of the 2015 Mw 7.8 Gorkha (Nepal) earthquake from inversions of ALOS-2 and GPS data, Geophysical Research Letters, 42, 7452-7458, $10.1002 / 2015 \mathrm{gl} 1065201,2015$.

774 Yechieli, Y., and Bein, A.: Response of groundwater systems in the Dead Sea Rift Valley to the Nuweiba earthquake: Changes in head, water chemistry, and near-surface effects, Journal of Geophysical Research: Solid Earth, 107, ETG 4-1-ETG 4-10, 10.1029/2001jb001100,

$777 \quad 2002$. Yun, S.: Strontium isotope composition and petrochemistry of the Cretaceous Chaeyaksan volcanics, Northern Yucheon volcanic field, South Korea, Jour. Geol. Soc. Korea, 34, 161$171,1998$. 
Figure. 2. (a) Location map of the study area and well locations. The upper right map shows the location of Gyeongju area on the southeastern Korean Peninsula. Red stars indicate the epicenters of the mainshock, foreshock, and the largest aftershock of the 2016 Gyeongju earthquakes. Magnitudes of the other aftershocks of $M_{L} \geq 3.0$ are also marked by circles illustrated by the color table. Gyeongju (yellow square) and the well locations (blue squares) are highlighted. (b) Geological map of the study area. The color legend shows the lithostratigraphic units comprising the Gyeongju area. Major faults comprising the Yangsan Fault System are denoted with abbreviations; YSF, Yangsan Fault; MoRF, Moryang Fault, MiRF, Miryang Fault; USF, Ulsan Fault, JNF, Jain Fault.

Figure. 3. Visualization of the component planes of the hydrogeochemical data for the Gyeongju area from the SOM results.

Figure. 4. U-matrix visualization and pattern of group formation of the SOM results in the Gyeongju area.

Figure. 5. Time series data of groundwater level in (a) KW 5; (b) KW 8; and (c) KW 11. The dates of the mainshock and aftershock of the earthquake $\left(M_{L} \geq 4.5\right)$ are marked as the orange colored line. 
Figure. 6. Time series data of the KW 11 well: (a) temperature and (b) electrical conductivities. The dates of the mainshock and aftershock of the earthquake $\left(M_{L} \geq 4.5\right)$ are marked as the orange colored line.

Figure. 7. Spatial distribution of radon concentrations in the Gyeongju area.

Figure. $8 .{ }^{87} \mathrm{Sr} /{ }^{86} \mathrm{Sr}$ vs $1 / \mathrm{Sr}$ plot for the groundwater samples. The rectangular boxes indicate each group defined considering the results of both SOM and lithostratigraphy. Green colored box is Group A (shale and sandstone), orange colored box is Group B (granite), yellow colored box is the KW 6 wells of Group C, and the red colored box is Group D (andesite).

Figure. 9. Spatial distribution of strontium concentrations and ${ }^{87} \mathrm{Sr} /{ }^{86} \mathrm{Sr}$ ratios in the Gyeongju area.

Figure. 10. Correlation plot of strontium and calcium values of the groundwater samples in Gyeongju area.

Figure. 11. (a) Conceptual model to explain the responses of the groundwater system induced by the Gyeongju earthquakes: active water-rock interactions increasing the geochemical signature (KW 9 in Group A), water level anomaly related to nonrecoverable deformation (KW 5 in Group B) (dotted line indicates the water table before the earthquakes, the solid line and red inverted triangle indicate the water table after the earthquakes), strong mixing between shallow and deep aquifer caused by sea 
Hydrol. Earth Syst. Sci. Discuss., https://doi.org/10.5194/hess-2018-360

Manuscript under review for journal Hydrol. Earth Syst. Sci.

Discussion started: 7 August 2018

(c) Author(s) 2018. CC BY 4.0 License.

water intrusion (KW 4 in the Group C), and strike-slip deformation leading to the

difference between the alluvial aquifer and the bedrock aquifer (Group D). (b) 
Hydrol. Earth Syst. Sci. Discuss., https://doi.org/10.5194/hess-2018-360

Hydrology and Manuscript under review for journal Hydrol. Earth Syst. Sci.

Discussion started: 7 August 2018

(c) Author(s) 2018. CC BY 4.0 License.

Table 1. The mainshock and aftershocks data $(M L \geq 3.5)$ of the Gyeongju earthquake.

\begin{tabular}{cccc}
\hline Date, time & $\mathrm{M}_{L}$ & Longitude & Latitude \\
\hline 2016-11-13, 21:52:57 & 3.5 & $36.36 \mathrm{~N}$ & $126.63 \mathrm{E}$ \\
2016-11-06, 06:26:22 & 3.5 & $33.76 \mathrm{~N}$ & $125.07 \mathrm{E}$ \\
2016-09-21, 11:53:54 & 3.5 & $35.75 \mathrm{~N}$ & $129.18 \mathrm{E}$ \\
2016-09-19, 20:33:58 & 4.5 & $35.74 \mathrm{~N}$ & $129.18 \mathrm{E}$ \\
2016-09-12, 20:34:22 & 3.6 & $35.78 \mathrm{~N}$ & $129.19 \mathrm{E}$ \\
$\mathbf{2 0 1 6 - 0 9 - 1 2 , ~ 2 0 : 3 2 : 5 4}$ & $\mathbf{5 . 8}$ & $\mathbf{3 5 . 7 6} \mathbf{N}$ & $\mathbf{1 2 9 . 1 9 ~ E}$ \\
$\mathbf{2 0 1 6 - 0 9 - 1 2 , ~ 1 9 : 4 4 : 3 2}$ & $\mathbf{5 . 1}$ & $\mathbf{3 5 . 7 7} \mathbf{N}$ & $\mathbf{1 2 9 . 1 9 ~ E}$ \\
\hline
\end{tabular}

${ }^{\dagger}$ The bold italics is the mainshock of the Gyeongju earthquakes. 
Hydrol. Earth Syst. Sci. Discuss., https://doi.org/10.5194/hess-2018-360

Manuscript under review for journal Hydrol. Earth Syst. Sci.

Discussion started: 7 August 2018

(c) Author(s) 2018. CC BY 4.0 License.
Hydrology and

Discussions

Table 2. Groundwater well information.

\begin{tabular}{|c|c|c|c|c|c|c|}
\hline Well ID & Longitude & Latitude & $\begin{array}{l}\text { Distance from } \\
\text { epicenter }(\mathrm{km})\end{array}$ & Well type & Lithostratigraphic unit & $\begin{array}{l}\text { Sampling depth } \\
(\mathrm{m})\end{array}$ \\
\hline KW 1 & $36.17 \mathrm{~N}$ & $128.72 \mathrm{E}$ & 59.99 & Bedrock & $\begin{array}{c}\text { Hayang Group } \\
\text { (cretaceous grey, dark grey siltstone and shale) } \\
\text { Hayang Group }\end{array}$ & 30 \\
\hline KW 2 & $36.11 \mathrm{~N}$ & $128.92 \mathrm{E}$ & 45.85 & Bedrock & $\begin{array}{l}\text { (cretaceous greenish grey, } \\
\text { dark grey shale with carbonate and sandstone) }\end{array}$ & 50 \\
\hline KW 3 & $36.13 \mathrm{~N}$ & $129.26 \mathrm{E}$ & 41.82 & Bedrock & $\begin{array}{c}\text { Bulguksa Granite } \\
\text { (biotite granites of Late Cretaceous to Early Tertiary age) } \\
\text { Yeonil Group }\end{array}$ & 20 \\
\hline KW 4 & $36.00 \mathrm{~N}$ & $129.31 \mathrm{E}$ & 29.33 & Alluvial, Bedrock & $\begin{array}{l}\text { (light brown shale and mudstone coexisting } \\
\text { with conglomerate of Miocene age) }\end{array}$ & 28,35 \\
\hline KW 5 & $35.75 \mathrm{~N}$ & $129.32 \mathrm{E}$ & 12.57 & Alluvial, Bedrock & $\begin{array}{l}\text { Bulguksa Granite } \\
\text { (biotite granites of Late Cretaceous } \\
\text { to Early Tertiary age) }\end{array}$ & 8,39 \\
\hline KW 6 & $35.83 \mathrm{~N}$ & $129.41 \mathrm{E}$ & 21.51 & Alluvial, Bedrock & $\begin{array}{c}\text { Janggi Group } \\
\text { (andesite and tuff of Miocene age) }\end{array}$ & 20,30 \\
\hline KW 7 & $35.90 \mathrm{~N}$ & $129.27 \mathrm{E}$ & 16.94 & Alluvial, Bedrock & $\begin{array}{c}\text { Yeonil Group } \\
\text { (conglomerate of Miocene age) } \\
\text { Yucheon Group }\end{array}$ & 5,50 \\
\hline KW 8 & $35.75 \mathrm{~N}$ & $129.05 \mathrm{E}$ & 12.76 & Alluvial, Bedrock & $\begin{array}{c}\text { (andesite, porphyry andesite, } \\
\text { and brecciated andesite of Cretaceous age) } \\
\text { Hayang Group }\end{array}$ & 5,40 \\
\hline KW 9 & $35.82 \mathrm{~N}$ & $129.10 \mathrm{E}$ & 10.57 & Alluvial, Bedrock & $\begin{array}{l}\text { (black and greenish grey shale } \\
\text { with hornfels of Cretaceous age) }\end{array}$ & 10,50 \\
\hline KW 10 & $35.58 \mathrm{~N}$ & 129.21 E & 20.13 & Alluvial, Bedrock & $\begin{array}{c}\text { Hayang Group } \\
\text { (greenish grey and dark grey sandstone, siltstone, shale } \\
\text { coexisting with mudstone and conglomerate of Cretaceous } \\
\text { age) }\end{array}$ & 10,28 \\
\hline KW 11 & $35.62 \mathrm{~N}$ & $129.08 \mathrm{E}$ & 19.35 & Alluvial, Bedrock & Yucheon Group (granite of Cretaceous age) & 10,28 \\
\hline KW 12 & $35.75 \mathrm{~N}$ & $128.65 \mathrm{E}$ & 48.68 & Alluvial, Bedrock & $\begin{array}{c}\text { Bulguksa Granite (intrusive rocks and granite porphyry of } \\
\text { Cretaceous age) }\end{array}$ & 8,50 \\
\hline
\end{tabular}

${ }^{\dagger}$ Well type refers the aquifer characteristics of location of installed well. The alluvial refers the well installed in the alluvial aquifer. 
Hydrol. Earth Syst. Sci. Discuss., https://doi.org/10.5194/hess-2018-360

Manuscript under review for journal Hydrol. Earth Syst. Sci.

Discussion started: 7 August 2018

(c) Author(s) 2018. CC BY 4.0 License.
Hydrology and

Earth System

Sciences

Discussions

Table 3. Hydrogeochemical data collected after 2016 Gyeongju earthquake.

\begin{tabular}{|c|c|c|c|c|c|c|c|c|c|c|c|c|c|c|c|c|c|}
\hline Well ID & $\mathrm{Ca}$ & K & $\mathrm{Mg}$ & $\begin{array}{l}\mathrm{Na} \\
\quad(\mathrm{m}\end{array}$ & $\mathrm{Cl}$ & $\mathrm{SO}_{4}$ & $\mathrm{NO}_{3}$ & $\mathrm{HCO}_{3}$ & $\begin{array}{c}\mathrm{Sr} \\
(\mathrm{ppb})\end{array}$ & $\begin{array}{l}\text { Tem. } \\
\left({ }^{\circ} \mathrm{C}\right)\end{array}$ & $\mathrm{pH}$ & $\begin{array}{c}\mathrm{DO} \\
(\mathrm{mg} / \mathrm{L})\end{array}$ & $\begin{array}{c}\mathrm{EC} \\
(\mu \mathrm{s} / \mathrm{cm})\end{array}$ & $\begin{array}{c}\text { TDS } \\
(\mathrm{mg} / \mathrm{L})\end{array}$ & $\begin{array}{l}\text { Sal. } \\
(\%)\end{array}$ & $\begin{array}{l}\text { Radon } \\
\left(\mathrm{Bq} / \mathrm{m}^{3}\right)\end{array}$ & ${ }^{87} \mathrm{Sr} /{ }^{86} \mathrm{Sr}$ \\
\hline KW 1 & 86.0 & 2.27 & 33.7 & 63.1 & 13.6 & 247 & 0.52 & 292 & 3660 & 14.8 & 7.03 & 0.72 & 898 & 0.58 & 0.44 & 6693 & 0.712368 \\
\hline KW 2 & 48.7 & 1.31 & 15.9 & 21.0 & 15.5 & 34.6 & 15.9 & 182 & 3393 & 15 & 7.59 & 0.95 & 412.1 & 0.27 & 0.2 & 3193 & 0.709754 \\
\hline KW 3 & 13.8 & 0.56 & 3.27 & 51.8 & 32.5 & 7.92 & 13.1 & 91.2 & 31.3 & 15.5 & 7.87 & 3.16 & 294.2 & 0.19 & 0.14 & 2366 & 0.706575 \\
\hline KW 4-1 & 8.91 & 16.9 & 11.8 & 193 & 111 & 73.8 & 0.21 & 300 & 79.6 & 15 & 8.45 & 0.62 & 950 & 0.62 & 0.47 & 2416 & 0.708188 \\
\hline KW 4-2 & 6.32 & 6.33 & 7.78 & 778 & 721 & 45.7 & 0.25 & 846 & 225 & 15.9 & 8.26 & 0.66 & 3310 & 2.15 & 1.74 & 2425 & 0.707283 \\
\hline KW 5-1 & 17.7 & 2.67 & 7.07 & 13.0 & 9.45 & 49.5 & 13.5 & 31.2 & 147 & 15.4 & 7.52 & 2.24 & 213.1 & 0.14 & 0.1 & 15849 & 0.707610 \\
\hline KW 5-2 & 30.5 & 2.43 & 5.11 & 35.2 & 17.7 & 27.9 & 0.34 & 137 & 170 & 15.6 & 6.55 & 0.74 & 309.7 & 0.2 & 0.15 & 17575 & 0.707356 \\
\hline KW 6-1 & 1.76 & 3.79 & 0.99 & 74.4 & 21.6 & 26.0 & 0.28 & 124 & 18.1 & 15 & 6.87 & 0.64 & 315.5 & 0.21 & 0.15 & 225 & 0.706191 \\
\hline KW 6-2 & 1.59 & 1.75 & 0.68 & 146 & 33.9 & 17.0 & 0.14 & 257 & 65.1 & 14.9 & 8.15 & 0.69 & 530 & 0.34 & 0.26 & 368 & 0.711835 \\
\hline KW 7-1 & 15.8 & 0.91 & 5.75 & 15.7 & 11.1 & 2.47 & 1.15 & 90.2 & 117 & 16.1 & 7.29 & 0.8 & 180.1 & 0.12 & 0.09 & 1218 & 0.706590 \\
\hline KW 7-2 & 9.94 & 0.99 & 3.71 & 15.8 & 9.62 & 2.79 & 1.95 & 68.3 & 78.0 & 15.1 & 7.01 & 2.76 & 140.3 & 0.09 & 0.07 & 992 & 0.705688 \\
\hline KW 8-1 & 19.1 & 6.36 & 3.91 & 19.2 & 22.2 & 16.8 & 15.9 & 57.7 & 115 & 11.5 & 7.01 & 1.63 & 224.7 & 0.15 & 0.11 & 5974 & 0.708231 \\
\hline KW 8-2 & 12.7 & 0.33 & 2.02 & 18.5 & 3.52 & 15.3 & 0.81 & 64.4 & 75.0 & 14.6 & 7.3 & 0.82 & 146.8 & 0.03 & 0.02 & 23060 & 0.706177 \\
\hline KW 9-1 & 53.6 & 16.9 & 21.6 & 12.3 & 18.4 & 46.6 & 40.9 & 187 & 379 & 14.3 & 7.02 & 5.17 & 513 & 0.33 & 0.25 & 585 & 0.707919 \\
\hline KW 9-2 & 62.4 & 10.4 & 24.0 & 13.3 & 18.6 & 43.8 & 38.9 & 204 & 538 & 14.9 & 6.9 & 0.58 & 521 & 0.34 & 0.25 & 249 & 0.707469 \\
\hline KW 10-1 & 29.2 & 4.23 & 6.50 & 21.0 & 22.5 & 31.3 & 19.2 & 76.6 & 194 & 17.2 & 7.69 & 7.05 & 294.7 & 0.19 & 0.14 & 228 & 0.708353 \\
\hline KW 10-2 & 94.9 & 2.27 & 13.2 & 92.6 & 15.5 & 305 & 10.3 & 161 & 4052 & 16.3 & 2.27 & 7.07 & 865 & 0.56 & 0.43 & 758 & 0.712029 \\
\hline KW 11-1 & 11.7 & 2.11 & 1.93 & 8.38 & 7.04 & 13.1 & 12.8 & 32.6 & 82.6 & 9.4 & 7.53 & 11.26 & 215.9 & 0.14 & 0.1 & 4204 & 0.706385 \\
\hline KW 11-2 & 32.6 & 1.49 & 2.19 & 13.0 & 7.65 & 34.6 & 4.14 & 79.6 & 54.2 & 14.9 & 7.21 & 6.98 & 121.5 & 0.08 & 0.06 & 488 & 0.706122 \\
\hline KW 11-3 & 24.4 & 2.23 & 8.02 & 7.88 & 7.87 & 14.6 & 7.87 & 93.6 & 212 & 15 & 7.07 & 0.96 & 227.3 & 0.15 & 0.11 & 1950 & 0.709625 \\
\hline KW 12-1 & 20.9 & 5.02 & 5.61 & 15.4 & 12.9 & 34.7 & 18.7 & 51.0 & 134 & 15 & 6.34 & 3.81 & 231.6 & 0.15 & 0.11 & 1755 & 0.707885 \\
\hline KW 12-2 & 24.0 & 6.19 & 5.22 & 15.1 & 13.6 & 32.2 & 22.9 & 58.9 & 136 & 14.8 & 6.11 & 4.52 & 247.6 & 0.16 & 0.12 & 1088 & 0.708022 \\
\hline
\end{tabular}

KW \#\#-1 refers the alluvial aquifer well and KW \#\#-2 or no hyphen well refers the bedrock aquifer well. 
Hydrol. Earth Syst. Sci. Discuss., https://doi.org/10.5194/hess-2018-360

Manuscript under review for journal Hydrol. Earth Syst. Sci.

Discussion started: 7 August 2018

(c) Author(s) 2018. CC BY 4.0 License.
Hydrology and

(c) (i)

Table 4. Anomaly data of groundwater wells based on the grouping results.

\begin{tabular}{|c|c|c|c|c|c|c|c|c|c|c|}
\hline Group & & ell ID & Well type & $\begin{array}{c}\text { Groundwater } \\
\text { level }\end{array}$ & Temperature & $\mathrm{EC}$ & $\begin{array}{c}\text { Radon con. } \\
(\mathrm{H}:>15000 \\
\mathrm{L}:<800)\end{array}$ & $\begin{array}{l}\text { Radon con. } \\
\text { Difference }\end{array}$ & $\begin{array}{c}\text { Strontium con. } \\
(\mathrm{H}:>3000 \\
\mathrm{L}:<100)\end{array}$ & $\begin{array}{l}{ }^{87} \mathrm{Sr} /{ }^{86} \mathrm{Sr} \\
(\mathrm{H}:>0.709 \\
\mathrm{L}:<0.707)\end{array}$ \\
\hline \multirow{6}{*}{ A } & \multicolumn{2}{|c|}{ KW 1} & Bedrock & & & $\mathrm{O}$ & & & $\mathrm{H}$ & $\mathrm{H}$ \\
\hline & \multicolumn{2}{|c|}{ KW2 } & Bedrock & & & $\mathrm{O}$ & & & $\mathrm{H}$ & $\mathrm{H}$ \\
\hline & \multirow{2}{*}{ KW 9} & KW 9-1 & Alluvial & & & & $\mathrm{L}$ & & & \\
\hline & & KW 9-2 & Bedrock & & & & $\mathrm{L}$ & & & \\
\hline & \multirow{2}{*}{ KW 10} & KW 10-1 & Alluvial & & & & $\mathrm{L}$ & & & \\
\hline & & KW 10-2 & Bedrock & & & $\mathrm{O}$ & $\mathrm{L}$ & & $\mathrm{H}$ & $\mathrm{H}$ \\
\hline \multirow{5}{*}{ B } & \multicolumn{2}{|c|}{ KW 3} & Bedrock & & & & & & $\mathrm{L}$ & $\mathrm{L}$ \\
\hline & \multirow{2}{*}{ KW 5} & KW 5-1 & Alluvial & $\mathrm{O}$ & & & $\mathrm{H}$ & & & \\
\hline & & KW 5-2 & Bedrock & $\mathrm{O}$ & & & $\mathrm{H}$ & & & \\
\hline & \multirow{2}{*}{ KW 12} & KW 12-1 & Alluvial & & & & & & & \\
\hline & & KW 12-2 & Bedrock & & & & & & & \\
\hline \multirow{6}{*}{$\mathrm{C}$} & \multirow{2}{*}{ KW 4} & KW 4-1 & Alluvial & & & & & \multirow{2}{*}{$\mathrm{L}$} & $\mathrm{L}$ & \\
\hline & & KW 4-2 & Bedrock & & & & & & & \\
\hline & \multirow{2}{*}{ KW 6} & KW 6-1 & Alluvial & & & $\mathrm{O}$ & $\mathrm{L}$ & \multirow{2}{*}{ L } & $\mathrm{L}$ & $\mathrm{L}$ \\
\hline & & KW 6-2 & Bedrock & & & $\mathrm{O}$ & $\mathrm{L}$ & & $\mathrm{L}$ & $\mathrm{H}$ \\
\hline & \multirow{2}{*}{ KW 7} & KW 7-1 & Alluvial & & & & & \multirow{2}{*}{$\mathrm{L}$} & & $\mathrm{L}$ \\
\hline & & KW 7-2 & Bedrock & & & & $\mathrm{L}$ & & $\mathrm{L}$ & \\
\hline \multirow{4}{*}{ D } & \multirow{2}{*}{ KW 8} & KW 8-1 & Alluvial & $\mathrm{O}$ & & & & \multirow{2}{*}{$\mathrm{H}$} & & \\
\hline & & KW 8-2 & Bedrock & $\mathrm{O}$ & & & $\mathrm{H}$ & & $\mathrm{L}$ & $\mathrm{L}$ \\
\hline & \multirow{2}{*}{ KW 11} & KW 11-1 & Alluvial & $\mathrm{O}$ & $\mathrm{O}$ & $\mathrm{O}$ & $\mathrm{L}$ & \multirow{2}{*}{$\mathrm{H}$} & $\mathrm{L}$ & $\mathrm{L}$ \\
\hline & & KW 11-2 & Bedrock & $\mathrm{O}$ & $\mathrm{O}$ & $\mathrm{O}$ & & & & $\mathrm{H}$ \\
\hline
\end{tabular}

' 'O' refers that the anomaly was detected, 'H' refers the high concentration, and 'L' refers the low concentration. 
Hydrol. Earth Syst. Sci. Discuss., https://doi.org/10.5194/hess-2018-360

Manuscript under review for journal Hydrol. Earth Syst. Sci.

Discussion started: 7 August 2018

(C) Author(s) 2018. CC BY 4.0 License.

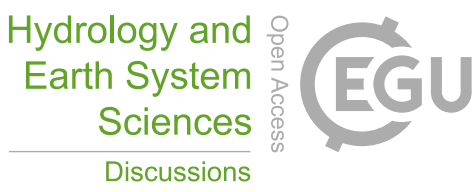

(c) (1)

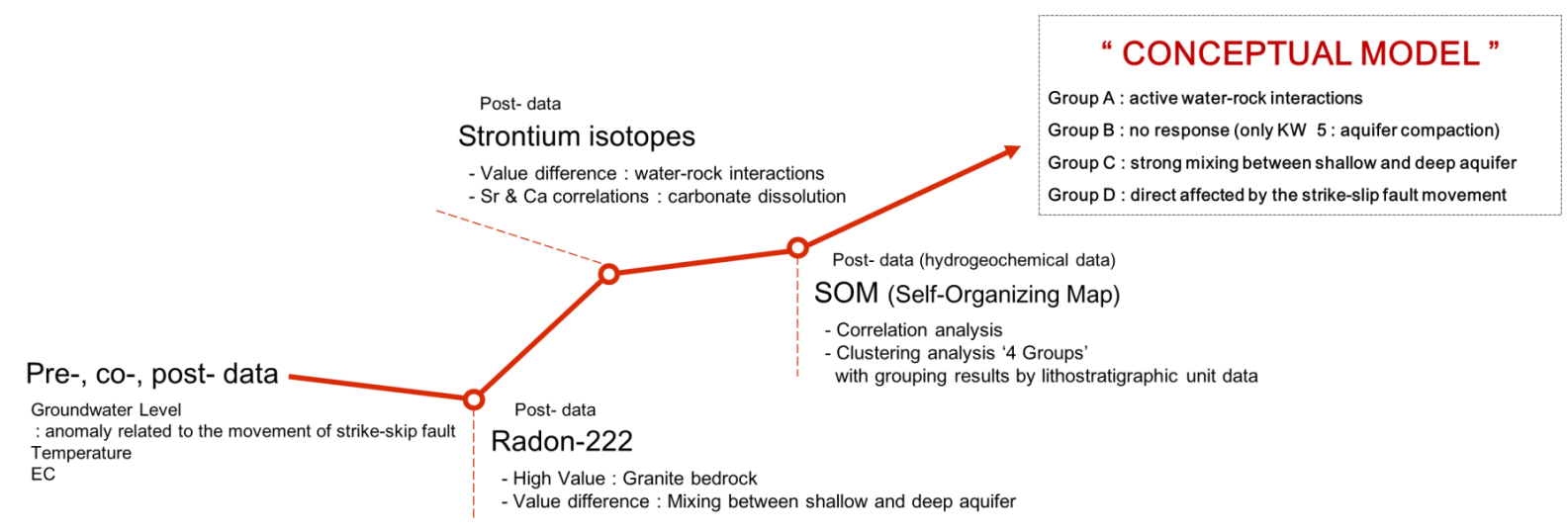

Figure. 1 
Hydrol. Earth Syst. Sci. Discuss., https://doi.org/10.5194/hess-2018-360

Manuscript under review for journal Hydrol. Earth Syst. Sci.

Discussion started: 7 August 2018

(c) Author(s) 2018. CC BY 4.0 License.
Hydrology and Earth System Sciences

Discussions

(c) (1)

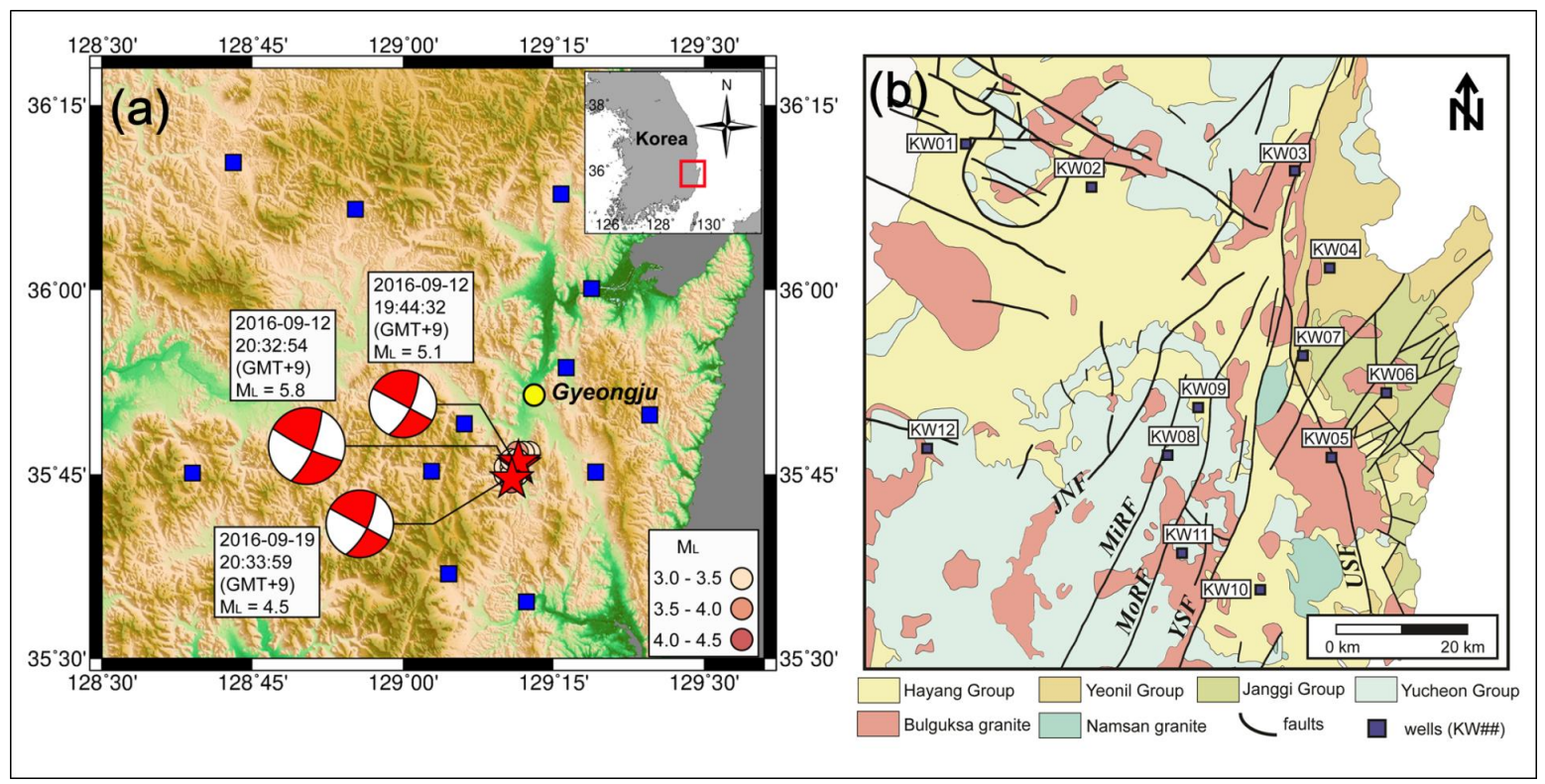

Figure. 2 
Hydrol. Earth Syst. Sci. Discuss., https://doi.org/10.5194/hess-2018-360

Manuscript under review for journal Hydrol. Earth Syst. Sci.

Discussion started: 7 August 2018

(c) Author(s) 2018. CC BY 4.0 License.

\section{Hydrology and Earth System \\ Sciences \\ Discussions}

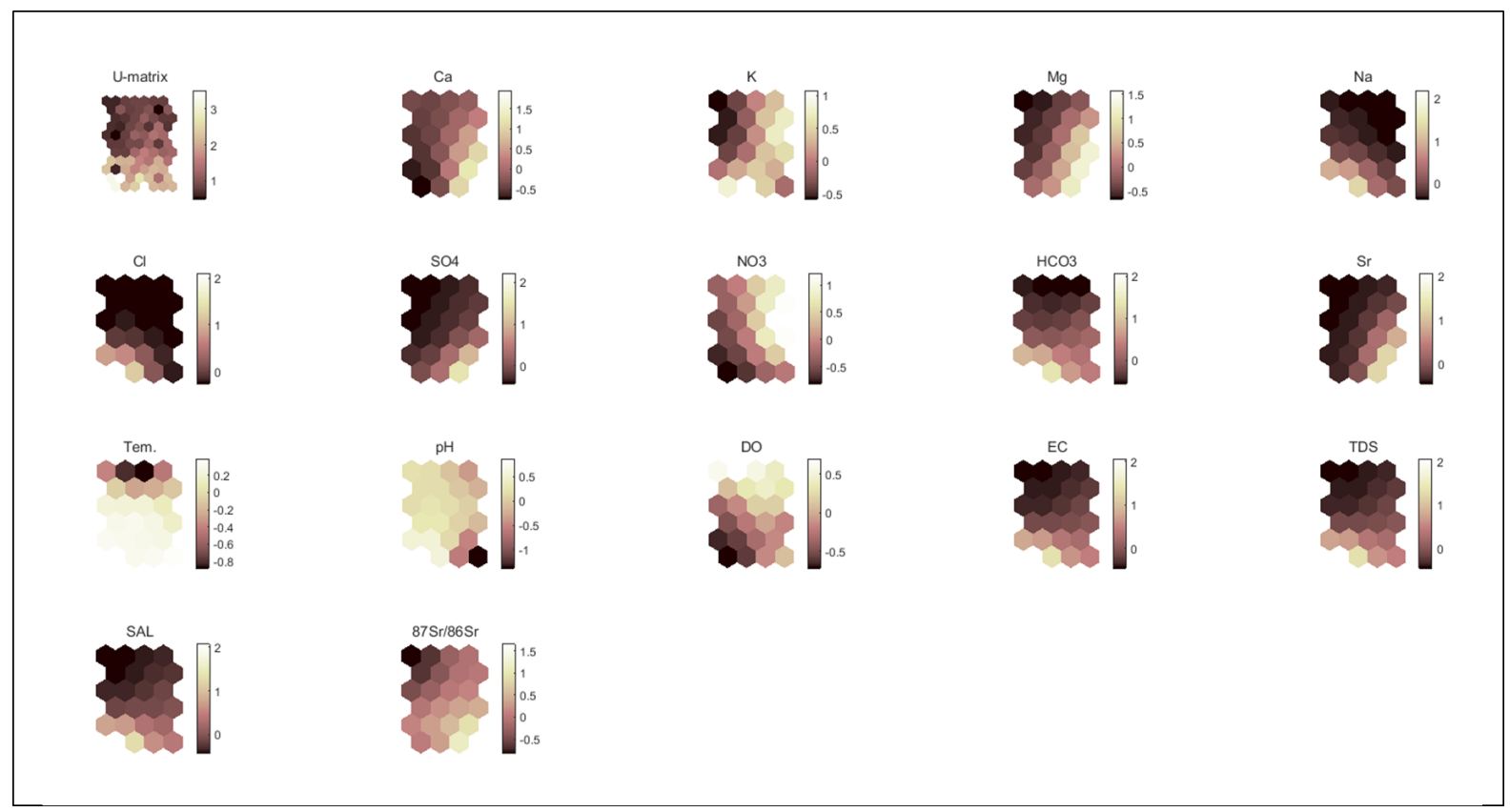

Figure. 3 
Hydrol. Earth Syst. Sci. Discuss., https://doi.org/10.5194/hess-2018-360

Manuscript under review for journal Hydrol. Earth Syst. Sci.

Discussion started: 7 August 2018

(c) Author(s) 2018. CC BY 4.0 License.

(c) (1)

\section{Hydrology and Earth System Sciences \\ Discussions}

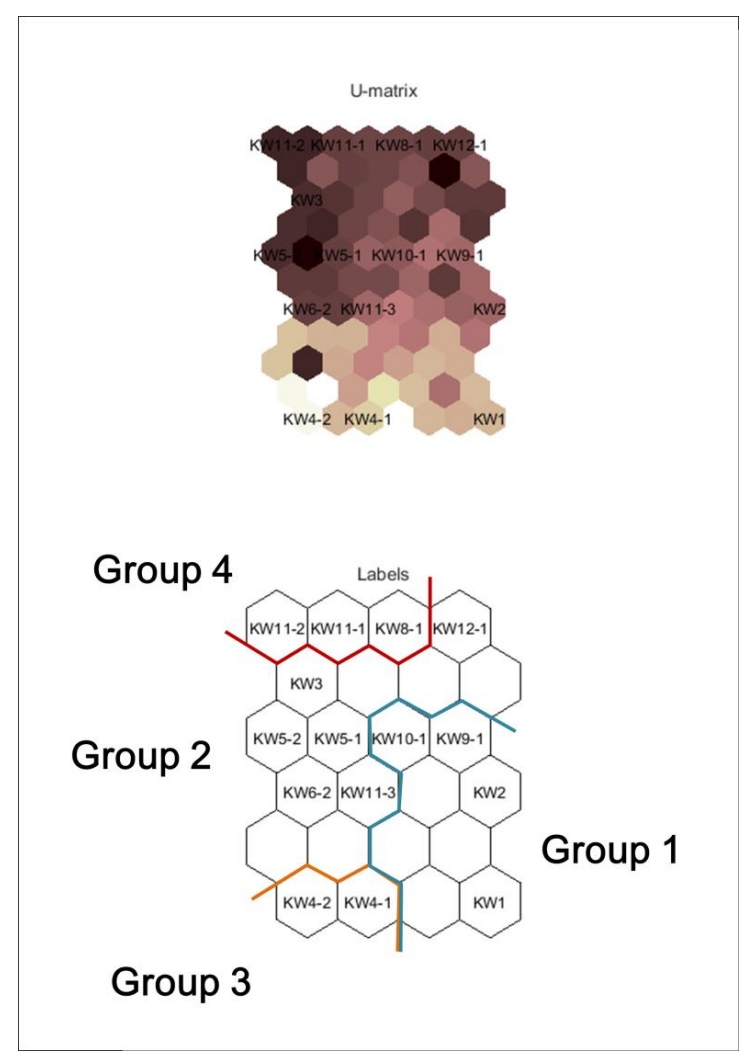

Figure. 4 
Hydrol. Earth Syst. Sci. Discuss., https://doi.org/10.5194/hess-2018-360

Manuscript under review for journal Hydrol. Earth Syst. Sci.

Discussion started: 7 August 2018

(c) Author(s) 2018. CC BY 4.0 License.
Hydrology and
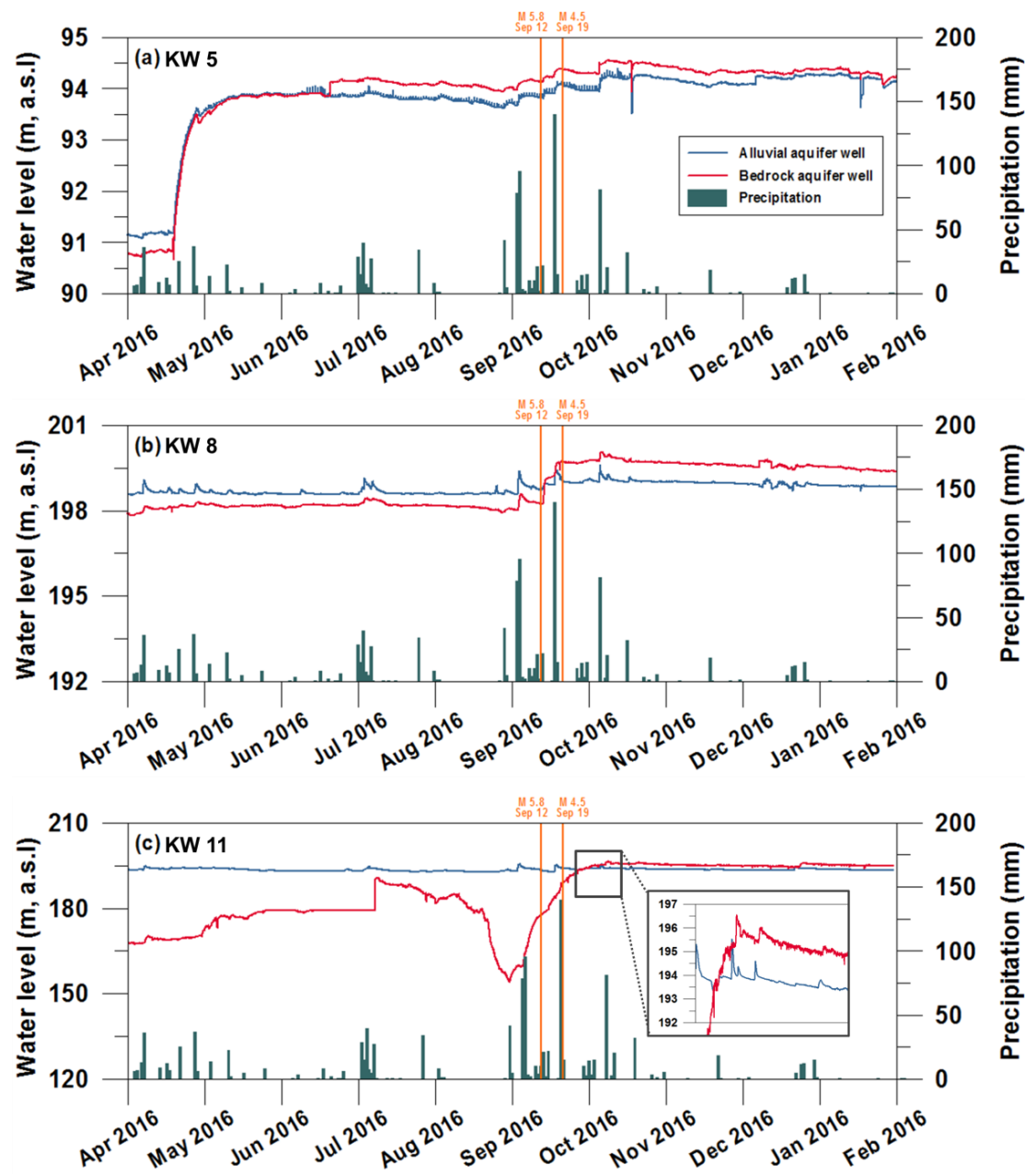

Figure. 5 
Hydrol. Earth Syst. Sci. Discuss., https://doi.org/10.5194/hess-2018-360

Manuscript under review for journal Hydrol. Earth Syst. Sci.

Discussion started: 7 August 2018

(c) Author(s) 2018. CC BY 4.0 License.

(c) (i)
Hydrology and
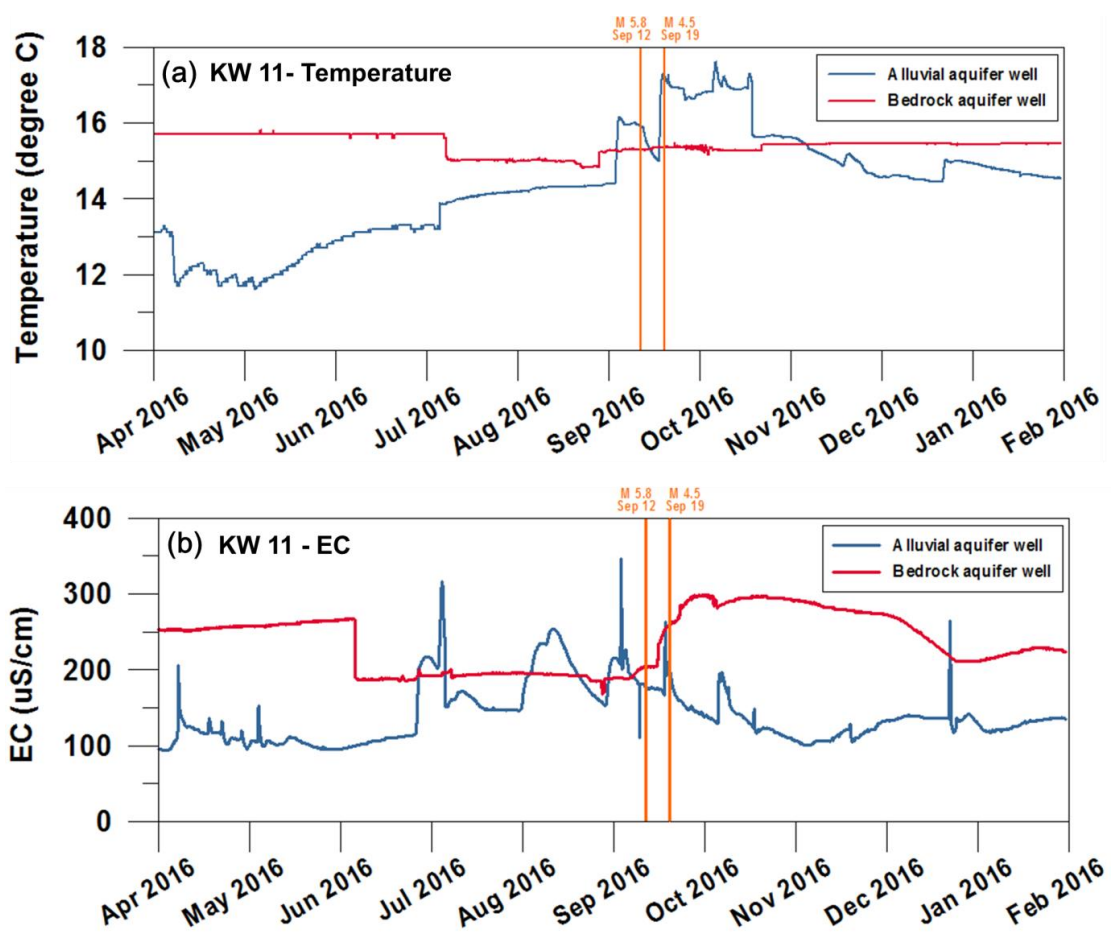

Figure. 6 
Hydrol. Earth Syst. Sci. Discuss., https://doi.org/10.5194/hess-2018-360 Manuscript under review for journal Hydrol. Earth Syst. Sci.

Discussion started: 7 August 2018

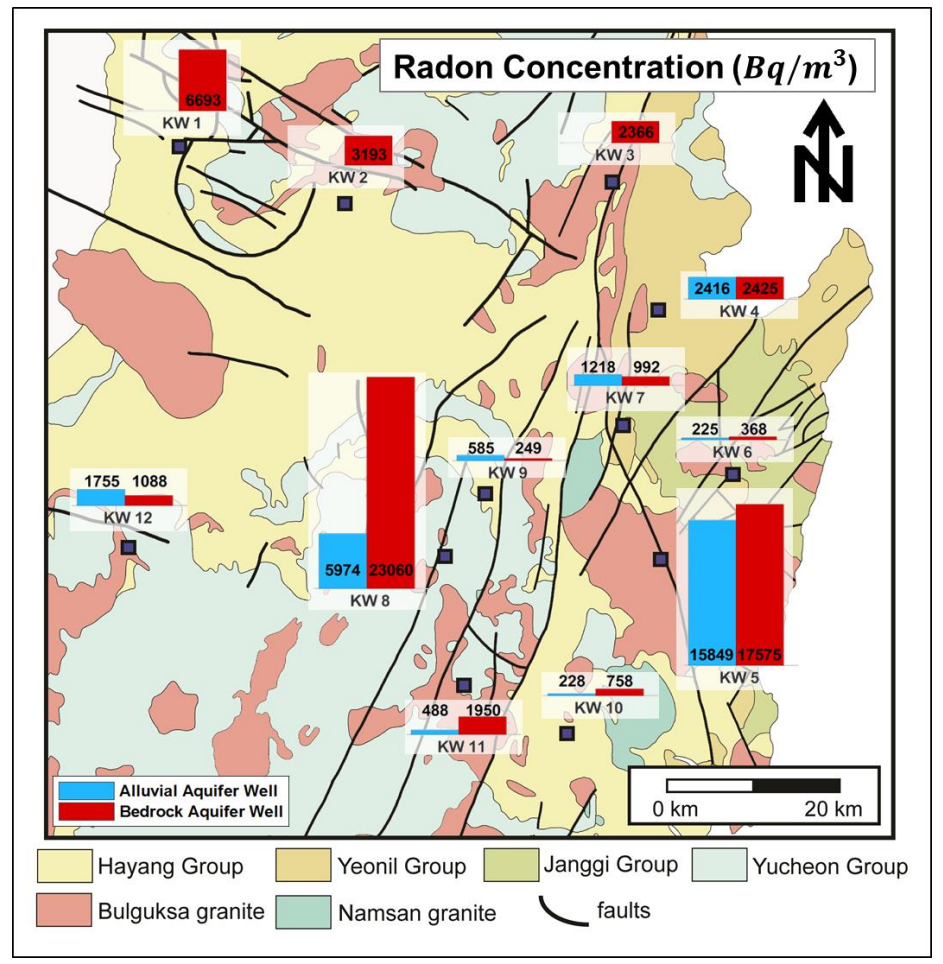

Figure. 7 
Hydrol. Earth Syst. Sci. Discuss., https://doi.org/10.5194/hess-2018-360

Manuscript under review for journal Hydrol. Earth Syst. Sci.

Discussion started: 7 August 2018

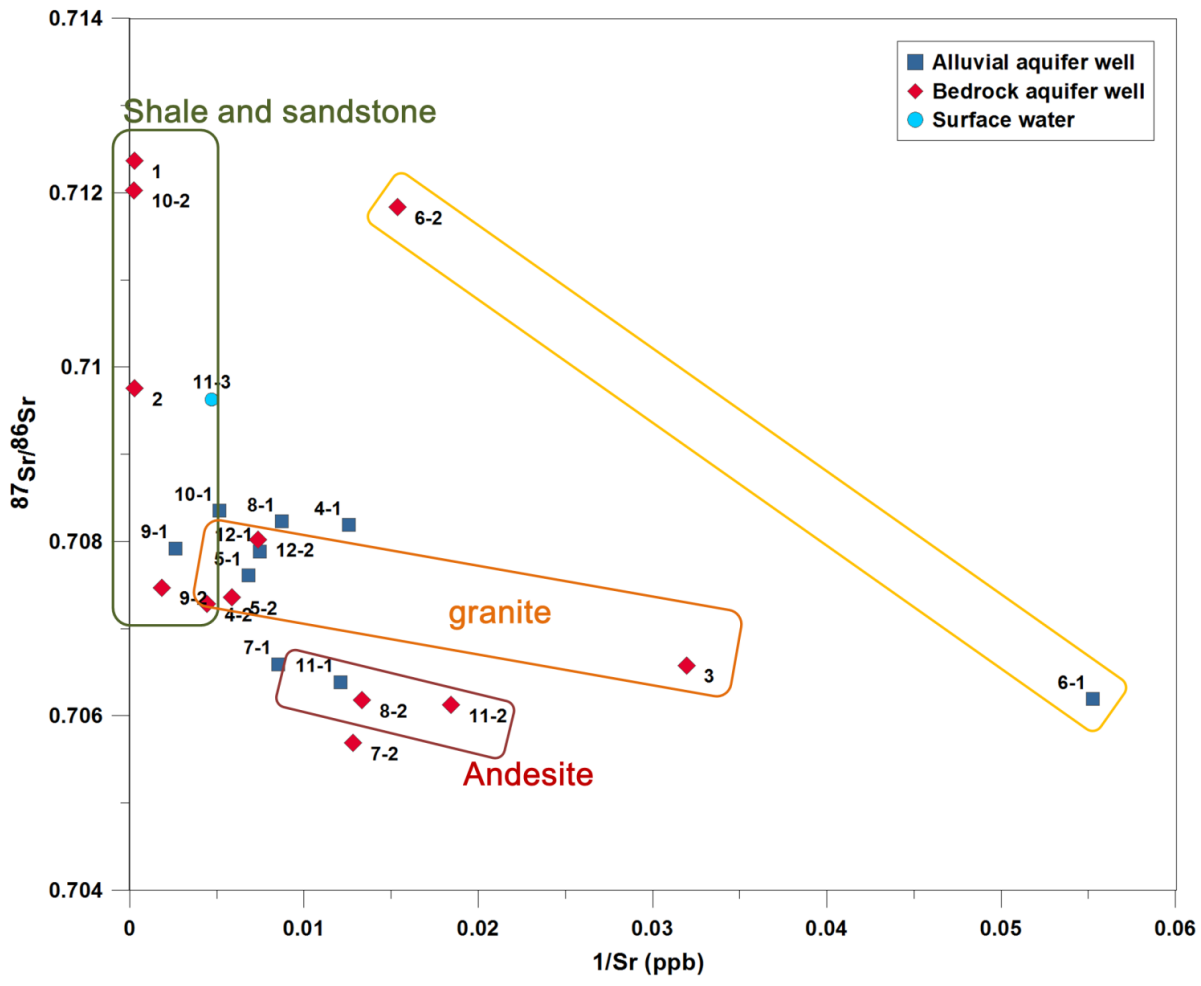

Figure. 8 
Hydrol. Earth Syst. Sci. Discuss., https://doi.org/10.5194/hess-2018-360

Manuscript under review for journal Hydrol. Earth Syst. Sci.

Discussion started: 7 August 2018

(c) Author(s) 2018. CC BY 4.0 License.
Hydrology and Earth System Sciences

Discussions (c) (1)

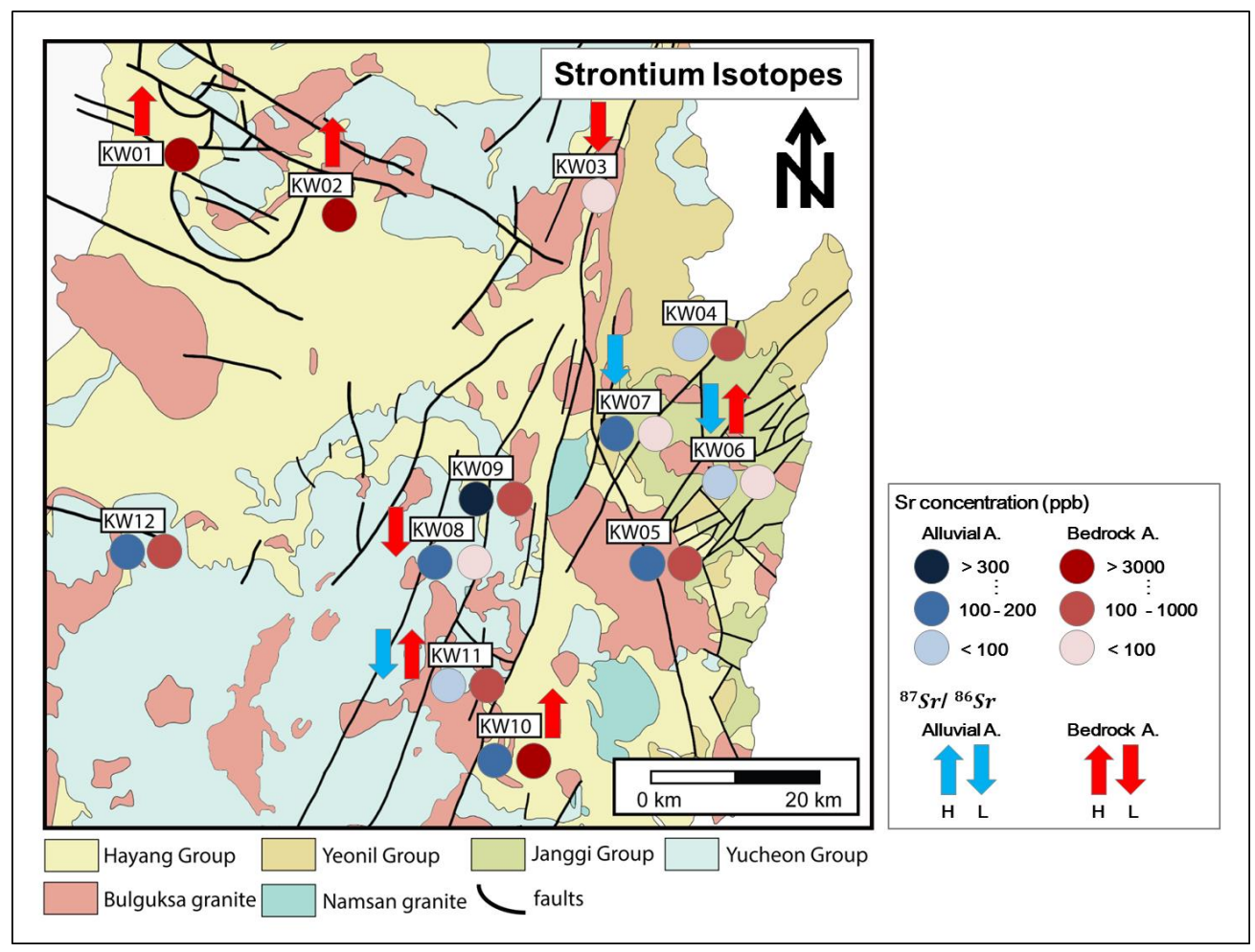

Figure. 9 
Hydrol. Earth Syst. Sci. Discuss., https://doi.org/10.5194/hess-2018-360

Manuscript under review for journal Hydrol. Earth Syst. Sci.

Discussion started: 7 August 2018

(c) Author(s) 2018. CC BY 4.0 License.

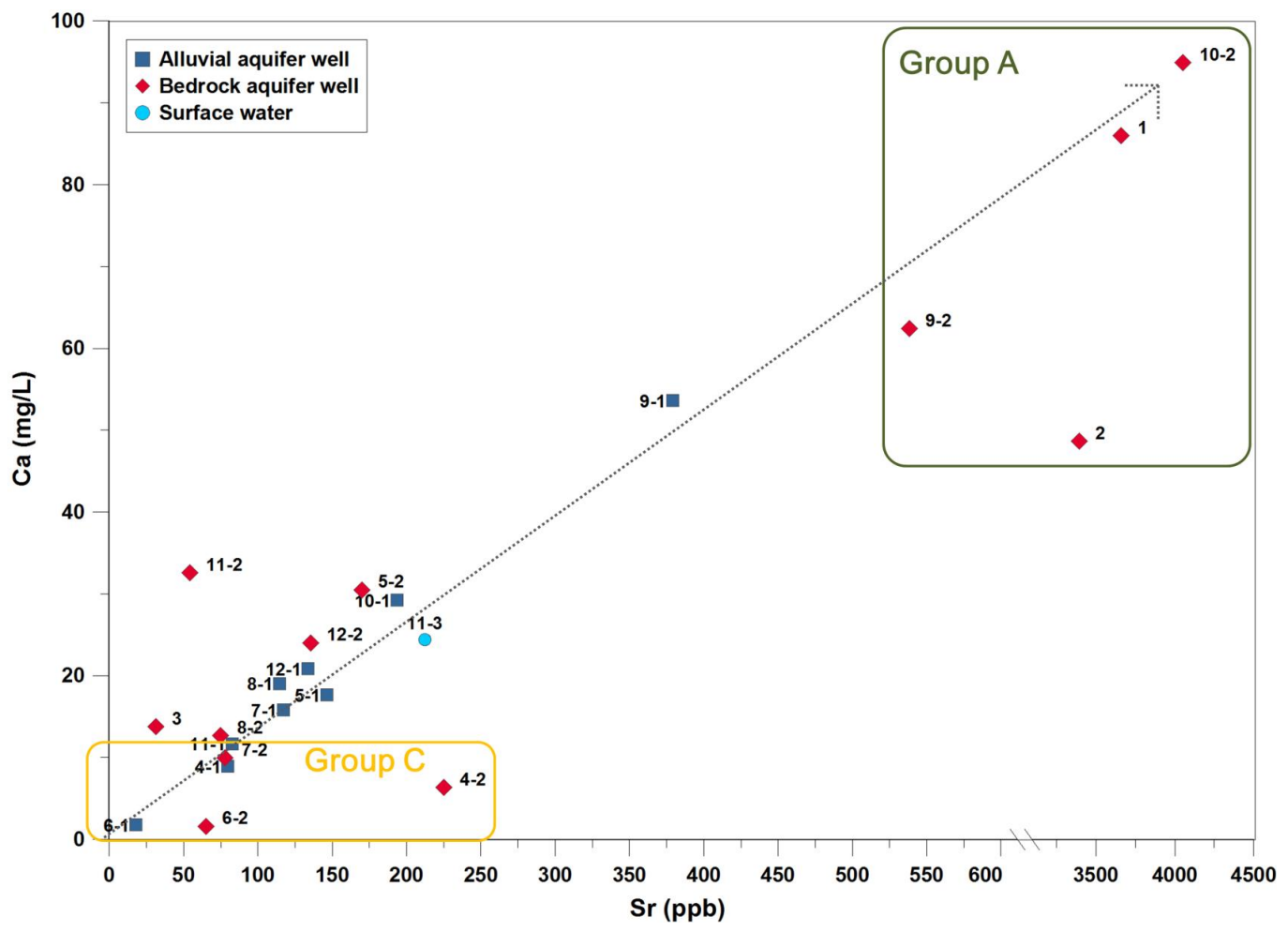

Figure. 10 
Hydrol. Earth Syst. Sci. Discuss., https://doi.org/10.5194/hess-2018-360

Manuscript under review for journal Hydrol. Earth Syst. Sci.

Discussion started: 7 August 2018

(c) Author(s) 2018. CC BY 4.0 License.
Hydrology and Earth System Sciences

Discussions (c) (i)

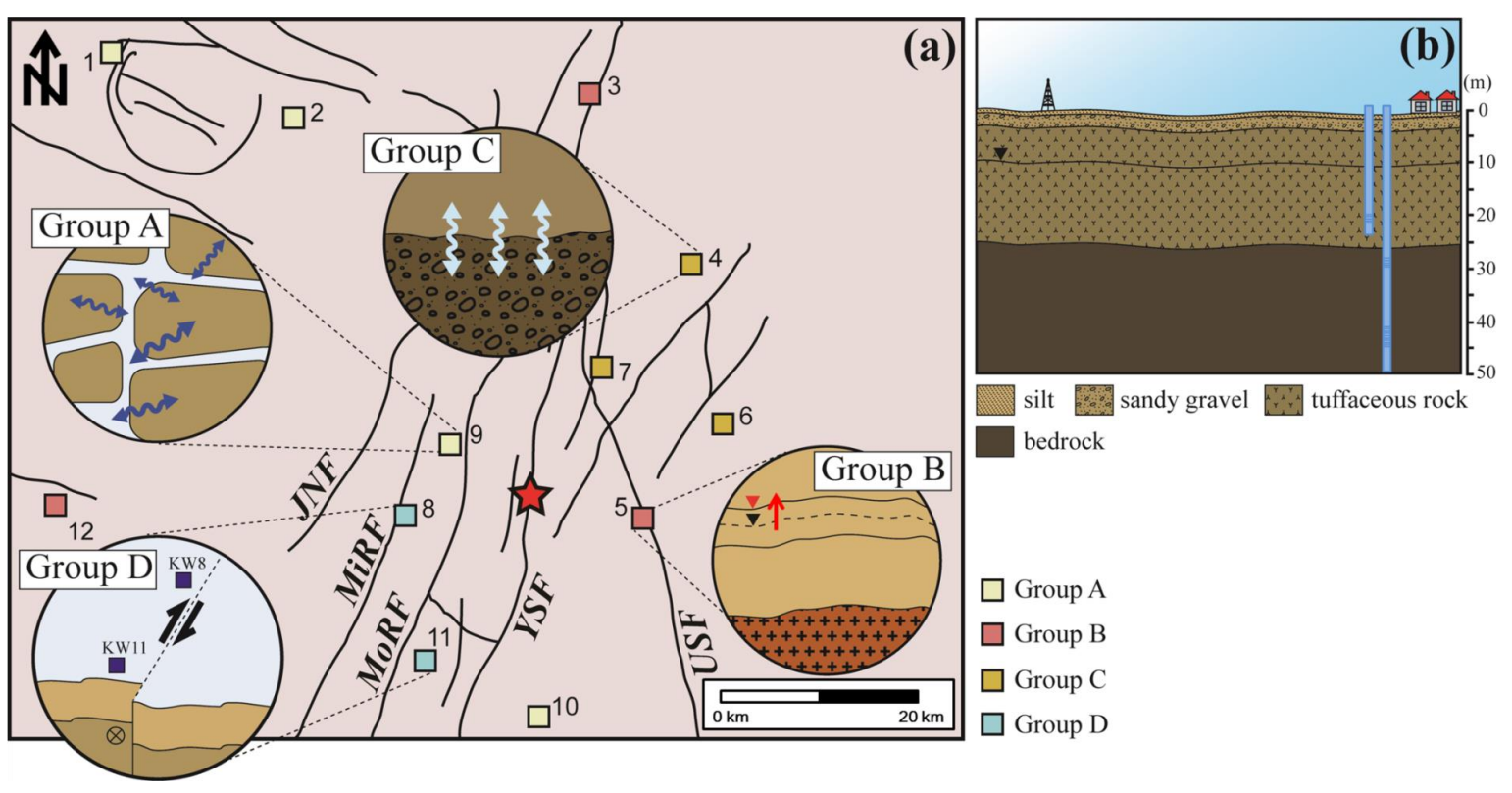

Figure. 11 